\title{
Uzaktan Eğitim Öğrencilerinin Öz-Yönetimli Öğrenme Becerilerinin İncelenmesi*
}

\section{Review of Self-Directed Learning Skills of Distance Education Students}

Burak YILMAZSOY**
Mehmet KAHRAMAN

Received: 01 June 2018

Research Article

Accepted: 03 April 2019

ABSTRACT: The goal of this research is to examine self-directed learning skills of distance education students in terms of different variables. The research is a descriptive study and it is based on survey research. There are a total of 151 students in the study group; Afyon Kocatepe University, Muğla Sttkı Koçman University, Anadolu University, Sakarya University, Istanbul University, Süleyman Demirel University, Gazi University and Karabük University students having distance education are the participants of this study. Data collection tool used in the study is developed by Aşkın (2015) within the scope of doctoral dissertation. "Self-directed Learning Skills Scale" is used for collecting data and "Personal Information Form" is used for determining the personal characteristics of participants. At the end of the research, it is determined that values about distance education students' self-directed learning skills and sub-factors are above the mid-point of the scale. It is observed that there is meaningful difference in terms of gender, university and motivation for postgraduate study sub-factors; it is seen that there is not meaningful difference in terms of education level in the complete scale and sub factors. On the other hand, it is determined that in terms of age variable, there is meaningful difference in the complete scale and sub-factors except self-confidence; in terms of grade point average (GPA) variable, there is meaningful difference in the complete scale and sub-factors except selfconfidence.

Keywords: distance education, self-management, motivation.

ÖZ: Bu araştırmada, uzaktan eğitim öğrencilerinin öz-yönetimli öğrenme becerilerinin farklı değişkenler açısından incelenmesi amaçlanmıştır. Araştırma tarama modelinde betimsel bir çalışmadır. Araştırmanın katılımcılarını Afyon Kocatepe Üniversitesi, Muğla Sitkı Koçman Üniversitesi, Anadolu Üniversitesi, Sakarya Üniversitesi, İstanbul Üniversitesi, Süleyman Demirel Üniversitesi, Gazi Üniversitesi ve Karabük Üniversitesinde uzaktan eğitim ile öğrenim gören toplam 151 öğrenci oluşmaktadır. Veri toplama aracı olarak, Aşkın (2015) tarafindan doktora tezi kapsamında geliştirilmiş olan "Öz-Yönetimli Öğrenme Becerileri Ölçeği” ve katılımcıların kişisel özelliklerini belirlemek amacıyla "Kişisel Bilgi Formu” kullanılmıştır. Araştırma sonuçlarına göre; uzaktan eğitim ile öğrenim gören öğrencilerin öz-yönetimli öğrenme becerileri ve alt faktörleri ölçek orta puanının üzerinde olduğu sonucuna ulaşılmıştır. Cinsiyet, üniversite, lisansüstü çalışma yapma isteklerine göre ölçeğin güdüleme alt faktöründe, yaş değişkenine göre ölçeğin tamamında ve özgüven alt faktörü haricinde tüm alt faktörlerde anlamlı farklılık olduğu, genel not ortalaması değişkenine göre ölçeğin tamamında ve özgüven alt faktörü haricinde tüm alt faktörlerde anlamlı farklılık olduğu sonuçlarına ulaşılmıştır.

Anahtar kelimeler: uzaktan eğitim, öz-yönetim, isteklendirme.

\footnotetext{
* This study was presented as an oral presentation at the 1st International Science and Education Congress held between 23-25 March 2018.

** Corresponding Author: Researcher, Muğla, Turkey, burakyilmazsoy@hotmail.com, https://orcid.org/0000-0001$5462-4247$

Asst. Prof. Dr., Afyon Kocatepe University, Afyonkarahisar, Turkey, kahraman@aku.edu.tr, https://orcid.org/0000-0002-2551-6623
}

Citation Information

Y1lmazsoy, B., \& Kahraman, M. (2019). Uzaktan eğitim öğrencilerinin öz-yönetimli öğrenme becerilerinin incelenmesi. Kuramsal Eğitimbilim Dergisi [Journal of Theoretical Educational Science], 12(2), 783-818. 


\section{Giriş}

Eğitim alandaki değişim ve gelişim süreci öğrencilerin öğrenme alışkanlıkları üzerinde değişikliklere neden olmakta ve öğrenenlerin içsel öğrenmelerine yönelik çalışmalar yapılmaktadır. Öz-yönetimli öğrenme öğrencilerin hedeflerine ulaşmak için kendi kendine öğretim planlamalarını yapması ve süreci takip etmesi olarak tanımlanabilir. Öz-yönetimli öğrenme genel olarak tanımlandığında; bireylerin hedeflerini netleştirme, öğrenme ihtiyaçlarını belirleme, öğrenme için uygun stratejileri seçme, değerlendirme ve öğrenme kaynaklarını belirlenmesi konusunda başkalarının desteği ile ya da dışarıdan destek olmadan süreç için öncelik (inisiyatif) almasıdır (Knowles, 1975). Öğrenenlerin kendi öğrenme yöntemlerine göre başarı durumları ve istekleri değişebilecektir. Öz-yönetimli öğrenme, nasıl ve ne öğrenileceği ve dişsal kaynaklara nasıl başvurulacağı ya da başvurulup başvurulmayacağı konusunda, öğrenenlerin kararlarıdır (Brookfield, 2009).

Alanyazın incelendiğinde öz-yönetimli öğrenmenin farklı tanımlarının olduğu görülmektedir. Bunlar;

- Whipp \& Chiarelli (2004), öğrenmeyi önemli ölçüde etkileyen bir dizi stratejiler bütünü olarak,

- Zimmerman (1989), öğrenenlerin kendi öğrenme süreçlerine üst bilişsel, güdüsel ve davranışsal olarak etkin bir şekilde katılım gösterebilme derecesi olarak,

- Pintrich (2000), öğrenenlerin amaçlarını oluşturduktan sonra bilişlerini, güdülerini ve davranışlarını gözlemleme, yönetme ve denetleme çabası içine girdikleri; kendi belirledikleri amaçlar ve içinde bulundukları öğrenme ortamı tarafından rehberlik edildikleri ve kısıtlandıkları etkin ve yapılandırmacı (constructivist) bir süreç olarak tanımlamaktadır.

Dünyada ve ülkemizde gelişim ve değişim sürecinde olan eğitim sisteminde uzaktan eğitim öğrencilerinin derse karşı olan istekleri ve öğrenme yöntemleri önem taşımaktadır. Öğrencilerin derse karşı olan ilgisi, kendi amaçları doğrultusunda eğitim programını yönlendirmesi ve takip etmesi öğrenci başarısı üzerinde etkili olabilecektir. Öğrenmenin bireyselleştirilmesi durumu, öz-yönetimli öğrenmenin yalnız olması gerektiği anlamına gelmemektedir (Aşkın, 2015). Öz-yönetimli öğrenme bireyin kendi öğrenme durumu gibi kavransa da grup etkinlikleriyle de öz-yönetimli öğrenme gerçekleştirilebilir. Uzaktan eğitimde de sanal sınıf ortamında gerekli ortam sağlandığında grup olarak öz-yönetimli öğrenme ortaya koyulabilecektir. Başarılı bir çevrimiçi öğrenme deneyimi için gerekli koşullardan biri öz-yönetimli (self-regulated) bir öğrenen olmaktır (Brooks, 1997; McLoughlin \& Marshall, 2000). Uzaktan eğitim öğrencilerine öğrenme süreçlerinin planlanması, kontrolü ve değerlendirilmesi konusunda büyük sorumluluk düşmektedir. (Moore \& Kearsley, 2012). Çevrimiçi öğrenmenin daha esnek olması, öğrenen merkezli olması (Kuo, Walker, Schroder ve Belland, 2014), fiziksel sınıf ortamındaki disiplinden uzak olması ve öğrencinin kendi öğrenme takibini yapması zorunluluğundan dolayı öğrencinin öz-yönetim ile kendi sürecini yönetmesi gerekmektedir.

Öz-yönetimli öğrenme ile ilgili literatür incelendiğinde öğrenenlerin öğrenme ihtiyacını ve öğrenme hedeflerini belirlediği, öğrenme süreçlerini yönettiği, zaman yönetimini yaptığı, alternatif öğrenme yollarını kullandığı, isteklendirme içinde olduğu, derse karşı ilgili olduğu, öğrenme konusunda istekli ve sorumluluk aldığı görülmektedir 
(Brockett \& Hiemstra, 1991; Fisher, King \& Tague, 2001; Guglielmino, 1977; Knowles, 1975; Oddi, 1984; Stockdale \& Brockett, 2004).

Öz-yönetimli öğrenmeye farklı isimlendirmeler yapılmıştır. Bunlar; araştırma yöntemi (inquiry method), öz-planlı öğrenme (self-planned learning), kendi kendine öğretim (self-instruction), bağımsız öğrenme (independent learning), kendi kendine çalışma (self-study), öz-girişimli öğrenme (self-initiated learning), öz-güdülenmeli öğrenme (self-motivated learning), kendi kendine eğitim (self-education), öz-öğrenimli öğrenme (auto-didacticism) ve kendi kendine öğrenme (autonomous learning) olarak siralanabilir (Knowles, 1975; Brookfield, 2009).

Öz-yönetimli öğrenen olabilmek için belli düşünce, tasarlama, planlama ve uygulama yapılması gereken unsurlar bulunmaktadır. Gibbons (2002), bireylerin özyönetimli olmaları için yapmaları gerekenleri şu şekilde ortaya koymuştur:

- Bireysel öğrenmeyi sağlamak için beceri ve süreçler geliştirme: hedef belirleme, planlama ve değerlendirme.

- Öğrenmeyi kontrol etmeyi sağlama: bakış açısı, tutum ve girişimciliği geliştirme.

- Bağımsız düşünme: analiz etme, sonuçlandırma, tartışma ve bir şeyler meydana getirmeyi ögrenme.

- Zamanı etkili bir şekilde yönetme.

- Kendi planlarını tasarlama ve tamamlama.

- Öğrenme etkinliklerini tasarlama ve tamamlama.

Değişme eğiliminde olan eğitim sisteminde teknoloji kullanımı ve internet teknolojilerindeki gelişmeler uzaktan eğitimi bir nebze kolaylaşmıştır. Eğitim sisteminde yer alan mevcut sorunlar ve teknoloji kullanımı uzaktan eğitimin ülkemizde ve dünyada yaygınlaşmasına yol açmıştır. Yüz yüze eğitimde önem arz eden özyönetimli öğrenme durumu uzaktan eğitimde mevcut sınırlılıkların ortadan kaldırılması ve öğrenci başarısının yükselmesi için çok daha fazla önem arz eden durumdadır.

\section{Araştırmanın Amacı}

Uzaktan eğitim ile öğrenim gören öğrencilerin kendi öğrenme hedeflerini belirlemeleri, planlamaları ve bu süreci yönetmeleri kaliteli eğitim için büyük önem taşımaktadır. Alanyazın incelendiğinde bu alanda yapılan çalışmaların yaygın olarak yurtdışı kaynaklı olduğu, ülkemizde bu alanda yapılan çalışmaların sınırlı olduğu görülmektedir. Değişim sürecinde olan eğitim sisteminde uzaktan eğitim öğrencilerinin öz-yönetimli öğrenme beceri durumlarının ehemmiyet arz etmesi, Türkiye'de bu alanda yapılan çalışmaların sınırlı olması ve yapılacak yeni araştırmalara yön vermesi durumu araştırmanın önemini arttırmaktadır.

Bu çalışmanın amacı, uzaktan eğitim öğrencilerinin öz-yönetimli öğrenme beceri düzeylerini belirleyerek, farklı değişkenler açısından incelemektir. $\mathrm{Bu}$ amaç doğrultusunda aşağıdaki sorulara cevap aranmıştır.

1. Uzaktan eğitim öğrencilerinin öz-yönetimli öğrenme beceri düzeyleri nedir?

2. Uzaktan eğitim öğrencilerinin öz-yönetimli öğrenme beceri düzeyleri;

a. Cinsiyet,

b. Üniversite, 

c. Lisansüstü çalışma yapma isteği,
d. Öğrenim düzeyi,
e. Yaş,
f. Genel not ortalaması değişkenine göre farklılık göstermekte midir?

\section{Yöntem}

$\mathrm{Bu}$ bölümde kullanılan araştırma modeline, araştırmanın katılımcılarına, veri toplama aracına ve veri analizine yer verilmiştir.

\section{Araştırma Modeli}

Uzaktan Eğitim öğrencelerinin öz-yönetimli öğrenme düzeylerinin incelendiği bu çalışma tarama modeline göre tasarlanmış betimsel bir çalışmadır. Tarama modelleri; geçmişte veya halen var olan bir durumu, var olduğu şekliyle betimlemeyi amaçlayan araştırma yaklaşımlarıdır. Araştırmaya konu olan olay, birey ya da nesne, kendi koşulları içinde ve olduğu gibi tanımlanmaya çalışılır. Tarama modelleri, çok sayıda elemandan oluşan bir evrende, evren hakkında genel bir yargıya varmak amacı ile evrenin tümü ya da ondan alınacak bir grup, örnek ya da örneklem üzerinde yapılan tarama düzenlemeleridir (Karasar, 2012).

\section{Çalışma Grubu}

Araştırmanın çalışma grubunu Afyon Kocatepe Üniversitesi (Bilgisayar Programcılığı ve İnternet ve Bilişim Teknolojileri Yönetimi ABD Yüksek Lisans), Muğla Sitkı Koçman Üniversitesi (Ekonomi ve Finans Tezsiz Yüksek Lisans, İşletme, Bilgisayar Programcilığı), Anadolu Üniversitesi (Çocuk Gelişimi, İşletme), Sakarya Üniversitesi (Mekatronik, Elektronik Teknolojileri, Bilgisayar Programcilığı), İstanbul Üniversitesi (Sosyoloji, Endüstri Mühendisliği), Gazi Üniversitesi (Bilişim Sistemleri), Süleyman Demirel Üniversitesi (Bilgi Yönetimi, Tıbbi Dokümantasyon ve Sekreterlik, Bilgisayar Programcılığı) ve Karabük Üniversitesinde (Çocuk Gelişimi) eğitim gören toplam 151 uzaktan eğitim öğrencisi oluşturmaktadır. Öğrencilerin gönüllülük esası ile doldurduğu ölçek, çevrimiçi ortamda uygulanmıştır. Veri toplama süresince ilgili üniversitelerde eğitim görmekte olan uzaktan eğitim öğrencilerine ulaşmak için Facebook eğitim gruplarında ve üniversitelerin uzaktan eğitim bölümlerinin Facebook sayfalarında paylaşım yapılmış ve 45 gün süresince veriler toplanmıştır. Araştırmanın tutarlılığı için farklı üniversitelerde okuyan öğrenciler uygun (elverişli) örnekleme yöntemi ile seçilmiştir. Uygun örnekleme yöntemi bulunan sınırlılıklar nedeniyle örneklemin kolay ulaşılabilir olması ve daha kolay uygulama yapılmasından dolayı seçilmiştir.

Çalışmaya katılan üniversite öğrencilerinin cinsiyet, üniversite, lisansüstü çalışma yapma isteği, öğrenim düzeyi, yaş ve genel not ortalamalarına göre dağılımları Tablo 1'de verilmiştir. 
Tablo 1

Çalışma Grubunun Değişkenlere Göre Dağılımı

\begin{tabular}{|c|c|c|c|}
\hline Değişkenler & Kategoriler & $N$ & $\%$ \\
\hline \multirow{2}{*}{ Cinsiyet } & Kadın & 80 & 53.0 \\
\hline & Erkek & 71 & 47.0 \\
\hline \multirow{8}{*}{ Üniversite } & Afyon Kocatepe Üniversitesi & 19 & 12.6 \\
\hline & Muğla Sıtkı Koçman Üniversitesi & 17 & 11.3 \\
\hline & Anadolu Üniversitesi & 17 & 11.3 \\
\hline & Sakarya Üniversitesi & 20 & 13.2 \\
\hline & İstanbul Üniversitesi & 25 & 16.6 \\
\hline & Süleyman Demirel Üniversitesi & 18 & 11.9 \\
\hline & Gazi Üniversitesi & 18 & 11.9 \\
\hline & Karabük Üniversitesi & 17 & 11.3 \\
\hline \multirow{3}{*}{$\begin{array}{l}\text { Lisansüstü Çalışma (Yüksek } \\
\text { Lisans/Doktora) Yapmayı } \\
\text { Düşünüyor Musunuz? }\end{array}$} & Evet & 97 & 64.2 \\
\hline & Hayır & 54 & 35.8 \\
\hline & Önlisans & 44 & 29.1 \\
\hline \multirow[t]{3}{*}{ Öğrenim Düzeyi } & Lisans & 69 & 45.7 \\
\hline & Yüksek Lisans & 38 & 25.2 \\
\hline & $18-22$ & 33 & 21.9 \\
\hline \multirow{2}{*}{ Yaş Aralığı } & $23-27$ & 37 & 24.5 \\
\hline & $28-32$ & 27 & 17.9 \\
\hline \multirow{5}{*}{ Genel Not Ortalaması } & $32+$ & 54 & 35.8 \\
\hline & $<2.00$ & 18 & 11.9 \\
\hline & $2.00-3.00$ & 57 & 37.7 \\
\hline & $3.00-3.50$ & 55 & 36.4 \\
\hline & $3.50-4.00$ & 21 & 13.9 \\
\hline \multicolumn{2}{|c|}{ Toplam } & 151 & 100 \\
\hline
\end{tabular}

\section{Veri Toplama Araçları}

Veri toplama aşamasında “Öz-Yönetimli Öğrenme Becerileri Ölçeği” ve kişisel bilgi formu kullanılmıştır. Uzaktan Eğitim öğrencilerin öz-yönetimli öğrenme beceri düzeylerini tespit etmek amacıyla Aşkın (2015) tarafından doktora tezi kapsamında geliştirilmiş olan “Öz-Yönetimli Öğrenme Becerileri Ölçeği” kullanılmıştır. 5'li likert tipinde 21 maddeden oluşan Öz-Yönetimli Öğrenme Becerileri Ölçeğindeki her bir soru için katılımcılara; 1 (Hiçbir Zaman), 2 (Nadiren), 3 (Bazen), 4 (Genellikle), 5 (Her Zaman) derecelerinde puan verilir. Anket sonucunda elde edilen minimum puan 21, maksimum puan 105 'dir. Ölçeğin güvenirlik çalışmalarında, Alpha değeri .895 olarak bulunmuştur. Bu çalışmada ise ölçeğin Cronbach Alfa katsayısı .94 olarak bulunmuştur 
Kişisel Bilgi Formunda; araştırmaya katılan öğrencilerin cinsiyet, üniversite, lisansüstü çalışma yapma istekleri, öğrenim düzeyi, yaş değişkeni ve genel not ortalaması bilgileri elde edilmiştir.

\section{Veri Analizi}

Araştırmada elde edilen anket verileri SPSS 20.0 programında analiz edilmiştir. Verilerin analizinde öncelikle dağılımın normalliğini belirlemek amacıyla KolmogrovSmirnov testi yapılmıştır. Büyüköztürk (2012), grup büyüklüğünün 50'den fazla olması durumunda puanların normalliğe uygunluğunun Kolmogrov - Smirnov testi ile yapılacağını ifade etmiştir. Yapılan analizler sonucunda verilerin normal dağıldı̆̆ belirlenmiştir. $\mathrm{Bu}$ nedenle verilerin analizinde ikili karşılaştırmalarda parametrik testlerden bağımsız gruplar t-testi ve çoklu karşılaştırmalarda tek yönlü varyans analizleri kullanılmıştır. Tek yönlü varyans analizi sonucunda anlamlı farklılığın çıktığı durumlarda grup varyanslarının eşit olmadığı için Tamhane Testi kullanılmıştır.

\section{Bulgular}

Araştırmanın bu bölümünde toplanan verilerden elde edilen bulgulara yer verilmiştir.

Tablo 2

Öğrencilerin Öz-Yönetimli Öğrenme Düzeyleri Toplam ve Alt Boyutları Ortalama Puanlarına İlişkin Bulgular

\begin{tabular}{cccccc}
\hline Durum & $n$ & En Düşük & En Yüksek & $\overline{\mathrm{X}}$ & ss \\
\hline Ölçeğin Tümü & 151 & 21.00 & 105.00 & 89.05 & 14.49 \\
1. Alt Boyut: Güdüleme & 151 & 7.00 & 35.00 & 31.29 & 5.09 \\
2. Alt Boyut: Öz Kontrol & 151 & 5.00 & 25.00 & 19.66 & 4.19 \\
3. Alt Boyut: Öz İzleme & 151 & 5.00 & 25.00 & 20.74 & 3.82 \\
4. Alt Boyut: Özgüven & 151 & 4.00 & 20.00 & 17.35 & 2.89 \\
\hline
\end{tabular}

Tablo 2'de öğrencilerin ölçeğin maddelerine vermiş olduğu cevaplardan almış oldukları toplam puan ve alt faktörlerden almış olduğu puan bilgileri yer almaktadır. Ölçekte alınabilecek en yüksek puan 105, en düşük puan 21'dir. Alt faktörler bazında da güdüleme alt faktöründe alınabilecek en yüksek puan 35 en düşük puan 7, öz-kontrol alt faktöründe alınabilecek en yüksek puan 25 en düşük puan 5, öz-izleme alt faktöründe alınabilecek en yüksek puan 25 en düşük puan 5 ve özgüven alt faktöründe alınabilecek en yüksek puan 20 en düşük puan 4'tür. Öğrencilerin ölçeğin tamamından aldığ 1 ortalama puanın ( $\bar{X}=89.05)$, güdüleme alt faktör ortalama puanının $(\bar{X}=32.29)$, özkontrol alt faktör puanının ( $\bar{X}=19.66)$, öz-izleme alt faktör ortalama puanının $(\bar{X}=20.74)$ ve özgüven alt faktör ortalama puanının $(\bar{X}=17.35)$ olduğu görülmektedir. Öğrencilerin kendi ders süreçlerini yönetebildiği, ders ve eğitim süreçlerinde istekli olduğu, kendine güvendiği, ders süreçlerini kendilerinin denetleme ve kontrollerini gerçekleştirdiği söylenebilir. 
Tablo 3

Öğrencilerin Cinsiyet Değişkenine Öz-Yönetimli Öğrenme Becerileri Toplam Puan ve Alt Faktörlere İlişkin Dăğlımları (t-testi)

\begin{tabular}{|c|c|c|c|c|c|c|c|}
\hline Alt Faktör & Cinsiyet & $n$ & $\bar{X}$ & S.S & s.d & $t$ & $p^{*}$ \\
\hline Ölçeğin & Kadın & 80 & 90.35 & 12.78 & 149 & 1.16 & .21 \\
\hline Tamamı & Erkek & 71 & 87.59 & 16.17 & & & \\
\hline \multirow{2}{*}{ Güdüleme } & Kadın & 80 & 31.91 & 16.17 & 149 & 1.58 & $.04 *$ \\
\hline & Erkek & 71 & 30.60 & 4.24 & & & \\
\hline \multirow{2}{*}{ Özkontrol } & Kadın & 80 & 19.82 & 5.86 & 149 & .50 & .29 \\
\hline & Erkek & 71 & 19.47 & 3.81 & & & \\
\hline \multirow{2}{*}{ Özizleme } & Kadın & 80 & 20.95 & 4.61 & 149 & .70 & .50 \\
\hline & Erkek & 71 & 20.50 & 3.52 & & & \\
\hline \multirow{2}{*}{ Özgüven } & Kadın & 80 & 17.66 & 4.15 & 149 & 1.41 & .85 \\
\hline & Erkek & 71 & 17.00 & 2.75 & & & \\
\hline
\end{tabular}

Tablo 3'de öğrencilerin cinsiyet değişkenine göre öz-yönetimli öğrenme düzeylerinin farklılaşıp farklılaşmadığı t-testi ile incelenmiştir. Öğrencilerin özyönetimli öğrenme düzeylerinde güdüleme alt faktöründe $[\mathrm{t}(149)=-1.58 ; \mathrm{p}<.05]$ anlamlı düzeyde farklılaşma olduğu,, diğer alt faktör ve ölçeğin tamamında anlamlı bir farklılık olmadığı görülmektedir. Anlamlı farklılık olmasa da kadın öğrencilerin öz-yönetimli öğrenme düzeylerinin ( $\bar{X}=90.35)$, erkek öğrencilerin öz-yönetimli öğrenme düzeylerinden $(\bar{X}=87.59)$ daha yüksek olduğu görülmektedir. Öğrencilerin öz-yönetimli öğrenme düzeyleri alt faktörlere göre incelendiğinde güdüleme alt faktöründe kadın öğrencilerin puan ortalaması $(\bar{X}=31.95)$, erkek öğrencilerin puan ortalamasından ( $\bar{X}=30.60)$, özkontrol alt faktöründe kadın öğrencilerin puan ortalaması ( $\bar{X}=19.82)$, erkek öğrencilerin puan ortalamasından ( $\bar{X}=19.47)$, özizleme alt faktöründe kadın öğrencilerin puan ortalaması $(\bar{X}=20.95)$, erkek öğrencilerin puan ortalamasından $(\bar{X}=20.50)$, özgüven alt faktöründe kadın öğrencilerin puan ortalaması ( $\bar{X}=17.66)$, erkek öğrencilerin puan ortalamasından $(\bar{X}=17.00)$ daha yüksek olduğu görülmektedir. Puan ortalamalarında meydana gelen farklılaşmanın nedeni olarak kadın öğrencilerin ders süreçlerinde daha titiz ve takipçi olması ve planlı yönetimleri gerçekleştirmelerinden kaynaklı olduğu söylenebilir. 
Tablo 4

Öğrencilerin Üniversite Değişkenine Göre Öz-Yönetimli Öğrenme Becerileri Toplam Puanına İlişkin Dağılımları (ANOVA)

\begin{tabular}{|c|c|c|c|c|c|c|c|c|c|}
\hline Üniversite & $n$ & $\bar{X}$ & s.s & $\begin{array}{l}\text { Varyans } \\
\text { Kaynağ } 1\end{array}$ & $\begin{array}{c}\text { Kareler } \\
\text { Toplamı }\end{array}$ & s.d & $\begin{array}{l}\text { Kareler } \\
\text { Ort. }\end{array}$ & $F$ & $p^{*}$ \\
\hline $\begin{array}{c}\text { Afyon } \\
\text { Kocatepe } \\
\text { Üniversitesi }\end{array}$ & 19 & 93.31 & 9.49 & $\begin{array}{l}\text { Grup } \\
\text { Aras1 }\end{array}$ & 2171.63 & 7 & 310.23 & 1.51 & .168 \\
\hline $\begin{array}{l}\text { Muğla Sitkı } \\
\text { Koçman } \\
\text { Üniversitesi }\end{array}$ & 17 & 88.70 & 9.65 & Grup İçi & 29331.93 & 143 & 205.11 & & \\
\hline $\begin{array}{l}\text { Anadolu } \\
\text { Üniversitesi }\end{array}$ & 17 & 87.00 & 8.83 & Toplam & 31503.57 & 150 & & & \\
\hline $\begin{array}{c}\text { Sakarya } \\
\text { Üniversitesi }\end{array}$ & 20 & 84.95 & 19.93 & & & & & & \\
\hline $\begin{array}{c}\text { İstanbul } \\
\text { Üniversitesi }\end{array}$ & 25 & 94.56 & 9.60 & & & & & & \\
\hline $\begin{array}{l}\text { Süleyman } \\
\text { Demirel } \\
\text { Üniversitesi }\end{array}$ & 18 & 84.44 & 20.45 & & & & & & \\
\hline $\begin{array}{c}\text { Gazi } \\
\text { Üniversitesi }\end{array}$ & 18 & 91.38 & 7.95 & & & & & & \\
\hline $\begin{array}{l}\text { Karabük } \\
\text { Üniversitesi }\end{array}$ & 17 & 85.82 & 20.94 & & & & & & \\
\hline Toplam & 151 & 89.05 & 14.49 & & & & & & \\
\hline
\end{tabular}

Tablo 4'te öğrencilerin öz-yönetimli öğrenme düzeyleri toplam puanının üniversite değişkenine göre farklılaşıp farklılaşmadığı tek yönlü varyans analizi (ANOVA) testi ile incelenmiştir. Öğrencilerin öz-yönetimli öğrenme düzeylerinde herhangi bir farklılaşma olmadığı tespit edilmiştir. Farklılaşma olmamasına rağmen İstanbul Üniversitesi ( $\bar{X}=94.56$ ), Afyon Kocatepe Üniversitesi ( $\bar{X}=91.38$ ) ve Gazi Üniversitesi ( $\bar{X}=93.31)$ öğrencilerinin öz-yönetimli öğrenme becerileri ortalama puanının diğer üniversitedeki öğrencilerden daha yüksek olduğu görülmektedir. 


\section{Tablo 5}

Öğrencilerin Üniversite Değişkenine Göre Öz-Yönetimli Öğrenme Becerileri Güdüleme Alt Faktörüne İlişkin Dăğlımları (ANOVA)

\begin{tabular}{|c|c|c|c|c|c|c|c|c|c|}
\hline Üniversite & $\mathrm{n}$ & $\bar{x}$ & S.S & $\begin{array}{l}\text { Varyans } \\
\text { Kaynağ1 }\end{array}$ & $\begin{array}{l}\text { Kareler } \\
\text { Toplamı }\end{array}$ & s.d & $\begin{array}{c}\text { Kareler } \\
\text { Ort. }\end{array}$ & $F$ & $p^{*}$ \\
\hline $\begin{array}{c}\text { Afyon } \\
\text { Kocatepe } \\
\text { Üniversitesi }\end{array}$ & 19 & 33.10 & 2.70 & $\begin{array}{l}\text { Grup } \\
\text { Arası }\end{array}$ & 370.04 & 7 & 52.86 & 2.14 & $.043^{*}$ \\
\hline $\begin{array}{l}\text { Muğla Sitkı } \\
\text { Koçman } \\
\text { Üniversitesi }\end{array}$ & 17 & 31.35 & 3.21 & Grup İçi & 3527.54 & 143 & 24.66 & & \\
\hline $\begin{array}{l}\text { Anadolu } \\
\text { Üniversitesi }\end{array}$ & 17 & 30.58 & 2.91 & Toplam & 3897.58 & 150 & & & \\
\hline $\begin{array}{c}\text { Sakarya } \\
\text { Üniversitesi }\end{array}$ & 20 & 29.50 & 7.54 & & & & & & \\
\hline $\begin{array}{c}\text { İstanbul } \\
\text { Üniversitesi }\end{array}$ & 25 & 33.36 & 3.03 & & & & & & \\
\hline $\begin{array}{c}\text { Süleyman } \\
\text { Demirel } \\
\text { Üniversitesi }\end{array}$ & 18 & 29.27 & 6.97 & & & & & & \\
\hline $\begin{array}{c}\text { Gazi } \\
\text { Üniversitesi }\end{array}$ & 18 & 32.44 & 1.85 & & & & & & \\
\hline $\begin{array}{l}\text { Karabük } \\
\text { Üniversitesi }\end{array}$ & 17 & 29.94 & 7.51 & & & & & & \\
\hline Toplam & 151 & 31.29 & 5.09 & & & & & & \\
\hline
\end{tabular}

Tablo 5'de öğrencilerin öz-yönetimli öğrenme düzeylerinin güdüleme alt faktörüne göre farklılaşıp farklılaşmadığı tek yönlü varyans analizi (ANOVA) testi ile incelenmiştir. Öğrencilerin öz-yönetimli öğrenme düzeylerinde güdüleme alt faktöründe anlamlı düzeyde $[F(7)=2.14 ; p<.05]$ farklılaşma olduğu tespit edilmiştir. İstanbul Üniversitesi ( $\bar{X}=33.36$ ), Afyon Kocatepe Üniversitesi $(\bar{X}=33.10)$, Gazi Üniversitesi $(\bar{X}=32.44)$ ve Muğla Sitkı Koçman Üniversitesi $(\bar{X}=31.35)$ öğrencilerinin puanlarının diğer üniversitedeki öğrencilere göre daha yüksek olduğu görülmektedir. Anlamlı düzeyde farklılaşmanın sebebi olarak puan ortalaması yüksek olan üniversitenin öğrencilerinin, puan ortalaması düşük olan üniversite öğrencilerine gore ders motivasyonlarının, ders takip ve devamlılıklarının daha yüksek olduğu söylenebilir. 
Tablo 6

Öğrencilerin Üniversite Değişkenine Göre Öz-Yönetimli Öğrenme Becerileri Özkontrol Alt Faktörüne İlişkin Dă̆llımları (ANOVA)

\begin{tabular}{|c|c|c|c|c|c|c|c|c|c|}
\hline Üniversite & $n$ & $\bar{x}$ & s.s & $\begin{array}{l}\text { Varyans } \\
\text { Kaynağı }\end{array}$ & $\begin{array}{l}\text { Kareler } \\
\text { Toplamı }\end{array}$ & s.d & $\begin{array}{l}\text { Kareler } \\
\text { Ort. }\end{array}$ & $F$ & $p^{*}$ \\
\hline $\begin{array}{c}\text { Afyon } \\
\text { Kocatepe } \\
\text { Üniversitesi }\end{array}$ & 19 & 20.57 & 4.08 & $\begin{array}{l}\text { Grup } \\
\text { Aras1 }\end{array}$ & 132.12 & 7 & 18.87 & 1.07 & .382 \\
\hline $\begin{array}{l}\text { Muğla Sitkı } \\
\text { Koçman } \\
\text { Üniversitesi }\end{array}$ & 17 & 18.94 & 3.57 & Grup İçi & 2507.65 & 143 & 17.53 & & \\
\hline $\begin{array}{l}\text { Anadolu } \\
\text { Üniversitesi }\end{array}$ & 17 & 19.00 & 3.20 & Toplam & 2639.77 & 150 & & & \\
\hline $\begin{array}{c}\text { Sakarya } \\
\text { Üniversitesi }\end{array}$ & 20 & 18.95 & 4.82 & & & & & & \\
\hline $\begin{array}{l}\text { İstanbul } \\
\text { Üniversitesi }\end{array}$ & 25 & 21.12 & 3.46 & & & & & & \\
\hline $\begin{array}{c}\text { Süleyman } \\
\text { Demirel } \\
\text { Üniversitesi }\end{array}$ & 18 & 18.55 & 5.89 & & & & & & \\
\hline $\begin{array}{c}\text { Gazi } \\
\text { Üniversitesi }\end{array}$ & 18 & 20.38 & 2.61 & & & & & & \\
\hline $\begin{array}{c}\text { Karabük } \\
\text { Üniversitesi }\end{array}$ & 17 & 19.11 & 4.99 & & & & & & \\
\hline Toplam & 151 & 19.66 & 4.19 & & & & & & \\
\hline
\end{tabular}

Tablo 6'da öğrencilerin öz-yönetimli öğrenme düzeylerinin özkontrol alt faktörüne göre farklılaşıp farklılaşmadığı tek yönlü varyans analizi (ANOVA) testi ile incelenmiştir. Öğrencilerin öz-yönetimli öğrenme düzeylerinin özkontrol alt faktöründe anlamlı düzeyde farklılaşma olmadığı tespit edilmiştir. Anlamlı farklılaşma olmasa da İstanbul Üniversitesi ( $\bar{X}=21.12$ ), Afyon Kocatepe Üniversitesi $(\bar{X}=20.57)$ ve Gazi Üniversitesi ( $\bar{X}=20.38)$ öğrencilerinin puanlarının diğer üniversitedeki öğrencilerin puan ortalamasından göre daha yüksek olduğu görülmektedir. 
Tablo 7

Öğrencilerin Üniversite Değişkenine Göre Öz-Yönetimli Öğrenme Becerileri Özİzleme Alt Faktörüne İlişkin Dağılımları (ANOVA)

\begin{tabular}{|c|c|c|c|c|c|c|c|c|c|}
\hline Üniversite & $n$ & $\bar{X}$ & S.s & $\begin{array}{l}\text { Varyans } \\
\text { Kaynağ1 }\end{array}$ & $\begin{array}{l}\text { Kareler } \\
\text { Toplamı }\end{array}$ & s.d & $\begin{array}{c}\text { Kareler } \\
\text { Ort. }\end{array}$ & $F$ & $p^{*}$ \\
\hline $\begin{array}{c}\text { Afyon } \\
\text { Kocatepe } \\
\text { Üniversitesi }\end{array}$ & 19 & 22.36 & 2.75 & $\begin{array}{l}\text { Grup } \\
\text { Aras1 }\end{array}$ & 141.12 & 7 & 20.16 & 1.40 & .209 \\
\hline $\begin{array}{l}\text { Muğla Sitkı } \\
\text { Koçman } \\
\text { Üniversitesi }\end{array}$ & 17 & 20.70 & 2.91 & Grup İçi & 2057.80 & 143 & 14.39 & & \\
\hline $\begin{array}{c}\text { Anadolu } \\
\text { Üniversitesi }\end{array}$ & 17 & 20.58 & 2.76 & Toplam & 2198.92 & 150 & & & \\
\hline $\begin{array}{c}\text { Sakarya } \\
\text { Üniversitesi }\end{array}$ & 20 & 19.25 & 4.95 & & & & & & \\
\hline $\begin{array}{c}\text { İstanbul } \\
\text { Üniversitesi }\end{array}$ & 25 & 21.60 & 3.01 & & & & & & \\
\hline $\begin{array}{c}\text { Süleyman } \\
\text { Demirel } \\
\text { Üniversitesi }\end{array}$ & 18 & 19.77 & 4.79 & & & & & & \\
\hline $\begin{array}{c}\text { Gazi } \\
\text { Üniversitesi }\end{array}$ & 18 & 21.22 & 3.29 & & & & & & \\
\hline $\begin{array}{c}\text { Karabük } \\
\text { Üniversitesi }\end{array}$ & 17 & 20.11 & 5.02 & & & & & & \\
\hline Toplam & 151 & 20.74 & 3.82 & & & & & & \\
\hline
\end{tabular}

Tablo 7'de öğrencilerin öz-yönetimli öğrenme düzeylerinin öz-izleme alt faktörüne göre farklılaşıp farklılaşmadığı tek yönlü varyans analizi (ANOVA) testi ile incelenmiştir. Öğrencilerin öz-yönetimli öğrenme düzeylerinin özkontrol alt faktöründe anlamlı düzeyde farklılaşma olmadığı tespit edilmiştir. Anlamlı düzeyde farklılaşma olmasa da Afyon Kocatepe Üniversitesi ( $\bar{X}=22.36)$, İstanbul Üniversitesi $(\bar{X}=21.60)$ ve Gazi Üniversitesi ( $\bar{X}=21.22$ ) öğrencilerinin puanlarının diğer üniversitedeki öğrencilere göre daha yüksek olduğu görülmektedir. 
Tablo 8

Öğrencilerin Üniversite Değişkenine Göre Öz-Yönetimli Öğrenme Becerileri Özgüven Alt Faktörüne İlişkin Dă̆ılımları (ANOVA)

\begin{tabular}{|c|c|c|c|c|c|c|c|c|c|}
\hline Üniversite & $n$ & $\bar{x}$ & s.s & $\begin{array}{l}\text { Varyans } \\
\text { Kaynağı }\end{array}$ & $\begin{array}{l}\text { Kareler } \\
\text { Toplamı }\end{array}$ & s.d & $\begin{array}{l}\text { Kareler } \\
\text { Ort. }\end{array}$ & $F$ & $p^{*}$ \\
\hline $\begin{array}{c}\text { Afyon } \\
\text { Kocatepe } \\
\text { Üniversitesi }\end{array}$ & 19 & 17.26 & 2.35 & $\begin{array}{l}\text { Grup } \\
\text { Aras1 }\end{array}$ & 52.34 & 7 & 7.47 & .89 & .517 \\
\hline $\begin{array}{l}\text { Muğla Sitkı } \\
\text { Koçman } \\
\text { Üniversitesi }\end{array}$ & 17 & 17.70 & 1.64 & Grup İçi & 1202.05 & 143 & 8.40 & & \\
\hline $\begin{array}{l}\text { Anadolu } \\
\text { Üniversitesi }\end{array}$ & 17 & 16.82 & 2.29 & Toplam & 1254.39 & 150 & & & \\
\hline $\begin{array}{c}\text { Sakarya } \\
\text { Üniversitesi }\end{array}$ & 20 & 17.25 & 3.73 & & & & & & \\
\hline $\begin{array}{l}\text { İstanbul } \\
\text { Üniversitesi }\end{array}$ & 25 & 18.48 & 1.53 & & & & & & \\
\hline $\begin{array}{l}\text { Süleyman } \\
\text { Demirel } \\
\text { Üniversitesi }\end{array}$ & 18 & 16.83 & 4.06 & & & & & & \\
\hline $\begin{array}{c}\text { Gazi } \\
\text { Üniversitesi }\end{array}$ & 18 & 17.33 & 2.24 & & & & & & \\
\hline $\begin{array}{c}\text { Karabük } \\
\text { Üniversitesi }\end{array}$ & 17 & 16.64 & 4.22 & & & & & & \\
\hline Toplam & 151 & 17.35 & 2.89 & & & & & & \\
\hline
\end{tabular}

Tablo 8'de öğrencilerin öz-yönetimli öğrenme düzeylerinin özgüven alt faktörüne göre farklılaşıp farklılaşmadığı tek yönlü varyans analizi (ANOVA) testi ile incelenmiştir. Öğrencilerin öz-yönetimli öğrenme düzeylerinin özkontrol alt faktöründe anlamlı düzeyde farklılaşma olmadığı tespit edilmiştir. Anlamlı düzeyde farklılaşma olmasa da İstanbul Üniversitesi ( $\bar{X}=18.48)$, Muğla Sıtk1 Koçman Üniversitesi ( $\bar{X}=17.70)$ ve Gazi Üniversitesi ( $\bar{X}=17.33)$ öğrencilerinin puanlarının diğer üniversitedeki öğrencilere göre daha yüksek olduğu görülmektedir. 
Tablo 9

Öğrencilerin Lisansüstü Çalışma Yapma İsteği Değişkenine Göre Öz-Yönetimli Öğrenme Becerileri Toplam Puan ve Alt Faktörlere İlişkin Dă̆gllımları (t-testi)

\begin{tabular}{cccccccc}
\hline Alt Faktör & $\begin{array}{c}\text { Lisansüstü } \\
\text { Çalışma İsteği }\end{array}$ & $n$ & $\bar{X}$ & s.s & s.d & $t$ & $p^{*}$ \\
\hline Ölçeğin & Evet & 97 & 89.70 & 12.35 & 149 & .73 & .062 \\
Tamamı & Hayır & 54 & 87.88 & 17.77 & & & \\
& Evet & 97 & 31.74 & 4.09 & 149 & 1.44 & $.011^{*}$ \\
Güdüleme & Hayır & 54 & 30.50 & 6.48 & & & \\
& Evet & 97 & 19.55 & 3.99 & 149 & -.41 & .256 \\
Özkontrol & Hayır & 54 & 19.85 & 4.56 & & & \\
& Evet & 97 & 21.00 & 3.35 & 149 & 1.11 & .075 \\
Özizleme & Hayır & 54 & 20.27 & 4.55 & & & \\
& Evet & 97 & 17.40 & 2.52 & 149 & .29 & .207 \\
Özgüven & Hayır & 54 & 17.25 & 3.48 & & & \\
\hline$* p<0.05$ & & & & & & &
\end{tabular}

Tablo 9'da öğrencilerin lisansüstü çalışma yapma isteklerine göre öz-yönetimli öğrenme düzeylerinin farklılaşıp farklılaşmadığı t-testi ile incelenmiştir. Öğrencilerin öz-yönetimli öğrenme düzeylerinde güdüleme alt faktöründe anlamlı düzeyde farklılaşma olduğu, diğer alt faktör ve ölçeğin tamamında anlamlı bir farklılık olmadığı görülmektedir. Anlamlı farklılık olmasa da Lisansüstü çalışma yapmak isteyen öğrencilerin öz-yönetimli öğrenme düzeylerinin ( $\bar{X}=89.70)$, Lisansüstü çalışma yapmak istemeyen öğrencilerin öz-yönetimli öğrenme düzeylerinden $(\bar{X}=87.88)$ daha yüksek olduğu görülmektedir. Öğrencilerin öz-yönetimli öğrenme düzeyleri alt faktörlere göre incelendiğinde; güdüleme alt faktöründe Lisansüstü çalışma yapmak isteyen öğrencilerin puan ortalaması $(\overline{\mathrm{X}}=31.74)$, Lisansüstü çalışma yapmak istemeyen öğrencilerin puan ortalamasından $(\bar{X}=30.50)$, özkontrol alt faktöründe Lisansüstü çalışma yapmak isteyen öğrencilerin puan ortalaması $(\bar{X}=19.55)$, Lisansüstü çalışma yapmak istemeyen ögrencilerin puan ortalamasından $(\bar{X}=19.85)$, özizleme alt faktöründe Lisansüstü çalışma yapmak isteyen öğrencilerin öğrencilerin puan ortalaması $(\bar{X}=21.00)$, Lisansüstü çalışma yapmak istemeyen öğrencilerin öğrencilerin puan ortalamasından ( $\bar{X}=20.27$ ), özgüven alt faktöründe Lisansüstü çalışma yapmak isteyen öğrencilerin puan ortalaması ( $\bar{X}=17.40)$, Lisansüstü çalışma yapmak istemeyen öğrencilerin öğrencilerin puan ortalamasından $(\bar{X}=17.25)$ daha yüksek olduğu görülmektedir. Güdüleme alt faktöründe anlamlı farklılaşmanın sebebi olarak Lisansüstü çalışma yapmak isteyen öğrencilerin daha istekli ve hevesli olma durumlarından kaynaklandlığı söylenebilir. 
Tablo 10

Öğrencilerin Öğrenim Düzeylerine Göre Öz-Yönetimli Öğrenme Becerileri Toplam Puanına İlişkin Dağılımları (ANOVA)

\begin{tabular}{|c|c|c|c|c|c|c|c|c|c|}
\hline $\begin{array}{c}\text { Öğrenim } \\
\text { Düzeyi }\end{array}$ & $n$ & $\bar{x}$ & s.s & $\begin{array}{l}\text { Varyans } \\
\text { Kaynağı }\end{array}$ & $\begin{array}{l}\text { Kareler } \\
\text { Toplamı }\end{array}$ & s.d & $\begin{array}{l}\text { Kareler } \\
\text { Ort. }\end{array}$ & $F$ & $p^{*}$ \\
\hline Önlisans & 44 & 88.56 & 28.16 & $\begin{array}{l}\text { Grup } \\
\text { Aras1 }\end{array}$ & 409.81 & 2 & 204.90 & .97 & .379 \\
\hline Lisans & 69 & 87.82 & 11.45 & Grup İçi & 31093.76 & 148 & 210.09 & & \\
\hline $\begin{array}{l}\text { Yüksek } \\
\text { Lisans }\end{array}$ & 38 & 91.84 & 14.92 & Toplam & 31503.57 & 150 & & & \\
\hline Toplam & 151 & 89.05 & 14.49 & & & & & & \\
\hline
\end{tabular}

Tablo 10'da öğrencilerin öz-yönetimli öğrenme düzeyleri toplam puanının öğrenim durumu değişkenine göre farklılaşıp farklılaşmadığı tek yönlü varyans analizi (ANOVA) testi ile incelenmiştir. Öğrencilerin öz-yönetimli öğrenme düzeylerinde herhangi bir farklılaşma olmadığı tespit edilmiştir. Farklılaşma olmamasına rağmen sırayla yüksek lisans öğrencilerinin ( $\bar{X}=91.84)$, önlisans $(\bar{X}=88.56)$ ve lisans öğrencilerinin $(\bar{X}=87.82)$ öz-yönetimli öğrenme becerileri puan ortalamalarından daha yüksek olduğu görülmektedir.

Tablo 11

Öğrencilerin Öğrenim Düzeylerine Göre Öz-Yönetimli Öğrenme Becerileri Güdüleme Alt Faktörüne İlişkin Dă̆ılımları (ANOVA)

\begin{tabular}{|c|c|c|c|c|c|c|c|c|c|}
\hline $\begin{array}{l}\text { Öğrenim } \\
\text { Düzeyi }\end{array}$ & $n$ & $\bar{x}$ & s.s & $\begin{array}{l}\text { Varyans } \\
\text { Kaynağı }\end{array}$ & $\begin{array}{l}\text { Kareler } \\
\text { Toplamı }\end{array}$ & s.d & $\begin{array}{c}\text { Kareler } \\
\text { Ort. }\end{array}$ & $F$ & $p^{*}$ \\
\hline Önlisans & 44 & 30.79 & 6.49 & $\begin{array}{l}\text { Grup } \\
\text { Aras1 }\end{array}$ & 74.06 & 2 & 37.03 & 1.43 & .242 \\
\hline Lisans & 69 & 30.95 & 5.03 & Grup İçi & 3823.52 & 148 & 25.83 & & \\
\hline $\begin{array}{l}\text { Yüksek } \\
\text { Lisans }\end{array}$ & 38 & 32.50 & 2.79 & Toplam & 3897.58 & 150 & & & \\
\hline Toplam & 151 & 31.29 & 5.09 & & & & & & \\
\hline
\end{tabular}

Tablo 11'de öğrencilerin öz-yönetimli öğrenme düzeyleri güdüleme alt faktörü puanının öğrenme düzeyi değişkenine göre farklılaşıp farklılaşmadığı tek yönlü varyans analizi (ANOVA) testi ile incelenmiştir. Öğrencilerin öz-yönetimli öğrenme düzeylerinin güdüleme alt faktöründe anlamlı düzeyde farklılaşma olmadığı tespit edilmişstir. Anlamlı düzeyde farklılaşma olmasa da yüksek lisans öğrencilerinin puanının $(\overline{\mathrm{X}}=32.50)$, lisans $(\overline{\mathrm{X}}=30.95)$ ve önlisans $(\overline{\mathrm{X}}=30.79)$ öğrencilerinin puanlarından daha yüksek olduğu görülmektedir. 


\section{Tablo 12}

Ögrrencilerin Öğrenim Düzeylerine Göre Öz-Yönetimli Öğrenme Becerileri ÖzKontrol Alt Faktörüne İlişkin Dă̆llımları (ANOVA)

\begin{tabular}{cccccccccc}
\hline $\begin{array}{c}\text { Öğrenim } \\
\text { Düzeyi }\end{array}$ & $n$ & $\overline{\mathrm{X}}$ & s.s & $\begin{array}{c}\text { Varyans } \\
\text { Kaynağı }\end{array}$ & $\begin{array}{c}\text { Kareler } \\
\text { Toplamı }\end{array}$ & s.d & $\begin{array}{c}\text { Kareler } \\
\text { Ort. }\end{array}$ & $F$ & $p^{*}$ \\
\hline Önlisans & 44 & 19.88 & 4.55 & $\begin{array}{c}\text { Grup } \\
\text { Aras1 }\end{array}$ & 60.00 & 2 & 30.00 & 1.72 & .182 \\
Lisans & 69 & 19.02 & 4.36 & Grup İçi & 2579.76 & 148 & 17.43 & & \\
$\begin{array}{c}\text { Yüksek } \\
\text { Lisans }\end{array}$ & 38 & 20.55 & 3.25 & Toplam & 2639.77 & 150 & & & \\
\hline Toplam & 151 & 19.66 & 4.19 & & & & & & \\
\hline
\end{tabular}

Tablo 12'de öğrencilerin öz-yönetimli öğrenme düzeyleri öz kontrol alt faktörü puanının öğrenme düzeyi değişkenine göre farklılaşıp farklılaşmadığı tek yönlü varyans analizi (ANOVA) testi ile incelenmiştir. Öğrencilerin öz-yönetimli öğrenme düzeylerinin öz-kontrol alt faktöründe anlamlı düzeyde farklılaşma olmadığı tespit edilmiştir. Anlamlı düzeyde farklılaşma olmasa da yüksek lisans öğrencilerinin puanının $(\bar{X}=20.55)$, önlisans $(\bar{X}=19.88)$ ve lisans $(\bar{X}=19.02)$ öğrencilerinin puanlarından daha yüksek olduğu görülmektedir.

Tablo 13

Öğrencilerin Öğrenim Düzeylerine Göre Öz-Yönetimli Öğrenme Becerileri Öz İzleme Alt Faktörüne İlişkin Dă̆llımları (ANOVA)

\begin{tabular}{|c|c|c|c|c|c|c|c|c|c|}
\hline $\begin{array}{l}\text { Öğrenim } \\
\text { Düzeyi }\end{array}$ & $n$ & $\bar{x}$ & s.s & $\begin{array}{l}\text { Varyans } \\
\text { Kaynağı }\end{array}$ & $\begin{array}{l}\text { Kareler } \\
\text { Toplamı }\end{array}$ & s.d & $\begin{array}{c}\text { Kareler } \\
\text { Ort. }\end{array}$ & $F$ & $p^{*}$ \\
\hline Önlisans & 44 & 20.61 & 4.60 & $\begin{array}{l}\text { Grup } \\
\text { Aras1 }\end{array}$ & 37.29 & 2 & 18.64 & 1.27 & .282 \\
\hline Lisans & 69 & 20.36 & 3.92 & Grup İçi & 2161.63 & 148 & 14.60 & & \\
\hline $\begin{array}{l}\text { Yüksek } \\
\text { Lisans }\end{array}$ & 38 & 21.57 & 2.33 & Toplam & 2198.92 & 150 & & & \\
\hline Toplam & 151 & 20.74 & 3.82 & & & & & & \\
\hline
\end{tabular}

Tablo 13'te öğrencilerin öz-yönetimli öğrenme düzeyleri öz-izleme alt faktörü puanının öğrenme düzeyi değişkenine göre farklılaşıp farklılaşmadığı tek yönlü varyans analizi (ANOVA) testi ile incelenmiştir. Öğrencilerin öz yönetimli öğrenme düzeylerinin öz izleme alt faktöründe anlamlı düzeyde farklılaşma olmadığı tespit edilmiştir. Anlamlı düzeyde farklılaşma olmasa da yüksek lisans öğrencilerinin puanının $(\bar{X}=21.50)$, önlisans $(\bar{X}=20.61)$ ve lisans $(\bar{X}=20.36)$ öğrencilerinin puanlarından daha yüksek olduğu görülmektedir. 
Tablo 14

Öğrencilerin Öğrenim Düzeylerine Göre Öz Yönetimli Öğrenme Becerileri Özgüven Alt Faktörüne İlişkin Dă̆llımları (ANOVA)

\begin{tabular}{|c|c|c|c|c|c|c|c|c|c|}
\hline $\begin{array}{l}\text { Öğrenim } \\
\text { Düzeyi }\end{array}$ & $n$ & $\bar{x}$ & s.s & $\begin{array}{l}\text { Varyans } \\
\text { Kaynağı }\end{array}$ & $\begin{array}{l}\text { Kareler } \\
\text { Toplamı }\end{array}$ & s.d & $\begin{array}{c}\text { Kareler } \\
\text { Ort. }\end{array}$ & $F$ & $p^{*}$ \\
\hline Önlisans & 44 & 17.27 & 3.76 & $\begin{array}{l}\text { Grup } \\
\text { Aras1 }\end{array}$ & 2.13 & 2 & 1.06 & .12 & .881 \\
\hline Lisans & 69 & 17.47 & 2.69 & Grup İçi & 1252.26 & 148 & 8.46 & & \\
\hline $\begin{array}{l}\text { Yüksek } \\
\text { Lisans }\end{array}$ & 38 & 17.21 & 2.00 & Toplam & 1254.39 & 150 & & & \\
\hline Toplam & 151 & 17.35 & 2.89 & & & & & & \\
\hline
\end{tabular}

Tablo 14'de öğrencilerin öz yönetimli öğrenme düzeyleri özgüven alt faktörü puanının öğrenme düzeyi değişkenine göre farklılaşıp farklılaşmadığı tek yönlü varyans analizi (ANOVA) testi ile incelenmiştir. Öğrencilerin öz yönetimli öğrenme düzeylerinin özgüven alt faktöründe anlamlı düzeyde farklılaşma olmadığı tespit edilmiştir. Anlamlı düzeyde farklılaşma olmasa da lisans öğrencilerinin puanının $(\bar{X}=17.47)$, önlisans $(\bar{X}=17.27)$ ve yüksek lisans $(\bar{X}=17.21)$ öğrencilerinin puanlarından daha yüksek olduğu görülmektedir.

\section{Tablo 15}

Öğrencilerin Yaş Değişkenine Göre $\ddot{O ̈}_{z}$ Yönetimli Öğrenme Becerileri Toplam Puanlarına İlişkin Dă̆llımları (ANOVA)

\begin{tabular}{cccccccccc}
\hline $\begin{array}{c}\text { Öğrenim } \\
\text { Düzeyi }\end{array}$ & $n$ & $\bar{X}$ & s.s & $\begin{array}{c}\text { Varyans } \\
\text { Kaynağı }\end{array}$ & $\begin{array}{c}\text { Kareler } \\
\text { Toplamı }\end{array}$ & s.d & $\begin{array}{c}\text { Kareler } \\
\text { Ort. }\end{array}$ & $F$ & $p^{*}$ \\
\hline $18-22$ & 33 & 82.57 & 19.67 & $\begin{array}{c}\text { Grup } \\
\text { Arası }\end{array}$ & 3079.40 & 3 & 1026.46 & 5.30 & $.002^{*}$ \\
$23-27$ & 37 & 88.05 & 11.80 & Grup İçi & 28424.17 & 147 & 193.36 & & \\
$28-32$ & 27 & 87.48 & 17.10 & Toplam & 31503.57 & 150 & & & \\
$32+$ & 54 & 94.48 & 8.01 & & & & & & \\
\hline Toplam & 151 & 89.05 & 14.49 & & & & & & \\
\hline$* p<0.05$ & & & & & & & &
\end{tabular}

Tablo 15'de öğrencilerin öz yönetimli öğrenme düzeyleri toplam puanının yaş değişkenine göre farklılaşıp farklılaşmadığı tek yönlü varyans analizi (ANOVA) testi ile incelenmiştir. Yapılan analiz sonucunda öz yönetimli öğrenme düzeyleri toplam puanlarındaki fark $[\mathrm{F}(147)=5.30 ; p<.05]$ istatistiksel olarak anlamlı bulunmuştur. Hangi gruplar arasında farklılaşma olduğunu ve grup ortalamasını ikili olarak farklı varyans yaklaşımı ile eş zamanlı karşılaştırmak için Tamhane Testi yapılmış analiz sonuçları Tablo 16'da gösterilmiştir. 
Tablo 16

Öğrencilerin Yaş Değişkenine Göre Tamamlayıcı İstatistiksel Analiz Sonuçları (Tamhane)

\begin{tabular}{|c|c|c|c|c|c|}
\hline Tamhane & Yaş & Yaş & $\begin{array}{c}\text { Ortalamalar } \\
\text { Arası Fark }\end{array}$ & Std. Hata & $p^{*}$ \\
\hline & \multirow[t]{3}{*}{$18-22$} & $23-27$ & 9.61905 & 3.93722 & .673 \\
\hline & & $28-32$ & .06667 & 4.75127 & .888 \\
\hline & & $32+$ & -8.89091 & 3.59475 & $.012^{*}$ \\
\hline & \multirow[t]{3}{*}{$23-27$} & $18-22$ & -9.61905 & 3.93722 & .673 \\
\hline & & $28-32$ & -9.55238 & 3.82233 & 1.000 \\
\hline & & $32+$ & -18.50996 & 2.22663 & .032 \\
\hline & \multirow[t]{3}{*}{$28-32$} & $18-22$ & -.06667 & 4.75127 & .888 \\
\hline & & $23-27$ & 9.55238 & 3.82233 & 1.000 \\
\hline & & $32+$ & -8.95758 & 3.46853 & $.274^{*}$ \\
\hline & \multirow[t]{3}{*}{$32+$} & $18-22$ & 8.89091 & 3.59475 & .012 \\
\hline & & $23-27$ & 18.50996 & 2.22663 & .032 \\
\hline & & $28-32$ & 8.95758 & 3.46853 & .274 \\
\hline
\end{tabular}

${ }^{*} p<0.05$

Tablo 16 incelendiğinde, 32 yaş ve üzeri öğrencilerin, 18-22 ve 23-27 yaş aralığındaki öğrenciler arasında anlamlı $(p<.05)$ farklılık olduğu görülmektedir. 32 yaş ve üzeri öğrencilerin öz yönetimli öğrenme becerileri puan ortalamalarının, 18-22 yaş ve 23-27 yaş aralığındaki öğrencilere göre anlamlı derecede daha yüksek olduğu bulgusuna ulaşılmıştır.

\section{Tablo 17}

Öğrencilerin Yaş Değişkenine Göre Öz Yönetimli Öğrenme Becerileri Güdüleme Alt Faktörüne İlişkin Dă̆llımları (ANOVA)

\begin{tabular}{cccccccccc}
\hline $\begin{array}{c}\text { Öğrenim } \\
\text { Düzeyi }\end{array}$ & $n$ & $\overline{\mathrm{X}}$ & s.s & $\begin{array}{c}\text { Varyans } \\
\text { Kaynağı }\end{array}$ & $\begin{array}{c}\text { Kareler } \\
\text { Toplamı }\end{array}$ & s.d & $\begin{array}{c}\text { Kareler } \\
\text { Ort. }\end{array}$ & $F$ & $p^{*}$ \\
\hline $18-22$ & 33 & 29.06 & 7.41 & $\begin{array}{c}\text { Grup } \\
\text { Arası }\end{array}$ & 379.27 & 3 & 126.42 & 5.28 & $.002^{*}$ \\
$23-27$ & 37 & 30.83 & 3.94 & $\begin{array}{c}\text { Grup İçi } \\
\text { 20 }\end{array}$ & 3518.31 & 147 & 23.93 & & \\
$28-32$ & 27 & 30.81 & 5.90 & Toplam & 3897.58 & 150 & & & \\
$32+$ & 54 & 33.22 & 2.35 & & & & & & \\
\hline Toplam & 151 & 31.29 & 5.09 & & & & & & \\
\hline$* p<0.05$ & & & & & & & &
\end{tabular}

Tablo 17'de öğrencilerin öz yönetimli öğrenme düzeyleri güdüleme alt faktörü puanının yaş değişkenine göre farklılaşıp farklılaşmadığ 1 tek yönlü varyans analizi (ANOVA) testi ile incelenmiştir. Yapılan analiz sonucunda öz yönetimli öğrenme 
düzeyleri güdüleme alt faktörü puanlarındaki fark istatistiksel olarak anlamlı bulunmuştur. Hangi gruplar arasında farklılaşma olduğunu ve grup ortalamasını ikili olarak farklı varyans yaklaşımı ile eş zamanlı karşıllaştırmak için Tamhane Testi yapılmış analiz sonuçları Tablo 18'de gösterilmiştir.

Tablo 18

Öğrencilerin Yaş Değişkenine Göre Tamamlayıcı Istatistiksel Analiz Sonuçları (Tamhane)

\begin{tabular}{|c|c|c|c|c|c|}
\hline Tamhane & Yaş & Yaş & $\begin{array}{c}\text { Ortalamalar } \\
\text { Arası Fark }\end{array}$ & Std. Hata & $p^{*}$ \\
\hline & \multirow[t]{3}{*}{$18-22$} & $23-27$ & -1.77723 & 1.44438 & .783 \\
\hline & & $28-32$ & -1.75421 & 1.71967 & .894 \\
\hline & & $32+$ & $-4.16162 *$ & 1.33005 & $.021 *$ \\
\hline & \multirow[t]{3}{*}{$23-27$} & $18-22$ & 1.77723 & 1.44438 & .783 \\
\hline & & $28-32$ & .02302 & 1.30782 & 1.000 \\
\hline & & $32+$ & $-2.38438 *$ & .72262 & $.010^{*}$ \\
\hline & \multirow[t]{3}{*}{$28-32$} & $18-22$ & 1.75421 & 1.71967 & .894 \\
\hline & & $23-27$ & -.02302 & 1.30782 & 1.000 \\
\hline & & $32+$ & -2.40741 & 1.18034 & .266 \\
\hline & \multirow[t]{3}{*}{$32+$} & $18-22$ & $4.16162 *$ & 1.33005 & $.021^{*}$ \\
\hline & & $23-27$ & $2.38438^{*}$ & .72262 & $.010^{*}$ \\
\hline & & $28-32$ & 2.40741 & 1.18034 & .266 \\
\hline
\end{tabular}

Tablo 18 incelendiğinde, 32 yaş ve üzeri öğrencilerin, 18-22 ve 23-27 yaş aralığındaki öğrenciler arasında anlamlı $(p<.05)$ farklılık olduğu görülmektedir. 32 yaş ve üzeri öğrencilerin öz yönetimli öğrenme becerileri güdüleme alt faktörü puan ortalamalarının, 18-22 yaş ve 23-27 yaş aralığındaki öğrencilere göre anlamlı derecede daha yüksek olduğu bulgusuna ulaşılmıştır. 
Tablo 19

Öğrencilerin Yaş Değişkenine Göre Öz Yönetimli Öğrenme Becerileri Öz Kontrol Alt Faktörüne İlişkin Dă̆llımları (ANOVA)

\begin{tabular}{cccccccccc}
\hline $\begin{array}{c}\text { Öğrenim } \\
\text { Düzeyi }\end{array}$ & $n$ & $\bar{X}$ & s.s & $\begin{array}{c}\text { Varyans } \\
\text { Kaynağı }\end{array}$ & $\begin{array}{c}\text { Kareler } \\
\text { Toplamı }\end{array}$ & s.d & $\begin{array}{c}\text { Kareler } \\
\text { Ort. }\end{array}$ & $F$ & $p^{*}$ \\
\hline $18-22$ & 33 & 17.84 & 4.63 & $\begin{array}{c}\text { Grup } \\
\text { Arası }\end{array}$ & 227.24 & 3 & 75.74 & 4.61 & $.004^{*}$ \\
$23-27$ & 37 & 19.35 & 3.93 & Grup İçi & 2412.52 & 147 & 16.41 & & \\
$28-32$ & 27 & 19.40 & 5.14 & Toplam & 2639.77 & 150 & & & \\
$32+$ & 54 & 21.11 & 3.00 & & & & & & \\
\hline Toplam & 151 & 19.66 & 4.19 & & & & & & \\
\hline$* p<0.05$ & & & & & & & &
\end{tabular}

Tablo 19'da öğrencilerin öz yönetimli öğrenme düzeyleri öz kontrol alt faktörü puanının yaş değişkenine göre farklılaşıp farklılaşmadığı tek yönlü varyans analizi (ANOVA) testi ile incelenmiştir. Yapılan analiz sonucunda öz yönetimli öğrenme düzeyleri öz kontrol alt faktörü puanlarındaki fark istatistiksel olarak anlamlı bulunmuştur. Hangi gruplar arasında farklılaşma olduğunu ve grup ortalamasını ikili olarak farklı varyans yaklaşımı ile eş zamanlı karşılaştırmak için Tamhane Testi yapılmış analiz sonuçları Tablo 20'de gösterilmiştir.

Tablo 20

Öğrencilerin Yaş Değişkenine Göre Tamamlayıcı Istatistiksel Analiz Sonuçları (Tamhane)

\begin{tabular}{|c|c|c|c|c|c|}
\hline Tamhane & Yaş & Yaş & $\begin{array}{c}\text { Ortalamalar } \\
\text { Aras1 Fark }\end{array}$ & Std. Hata & $p^{*}$ \\
\hline & \multirow[t]{3}{*}{$18-22$} & $23-27$ & -1.50287 & 1.03416 & .626 \\
\hline & & $28-32$ & -1.55892 & 1.27771 & .788 \\
\hline & & $32+$ & $-3.26263^{*}$ & .90511 & .004 \\
\hline & \multirow[t]{3}{*}{$23-27$} & $18-22$ & 1.50287 & 1.03416 & .626 \\
\hline & & $28-32$ & -.05606 & 1.18260 & 1.000 \\
\hline & & $32+$ & -1.75976 & .76500 & .139 \\
\hline & \multirow[t]{3}{*}{$28-32$} & $18-22$ & 1.55892 & 1.27771 & .788 \\
\hline & & $23-27$ & .05606 & 1.18260 & 1.000 \\
\hline & & $32+$ & -1.70370 & 1.07158 & .538 \\
\hline & \multirow[t]{3}{*}{$32+$} & $18-22$ & $3.26263 *$ & .90511 & .004 \\
\hline & & $23-27$ & 1.75976 & .76500 & .139 \\
\hline & & $28-32$ & 1.70370 & 1.07158 & .538 \\
\hline
\end{tabular}


Tablo 20 incelendiğinde 32 yaş ve üzeri öğrencilerle, 18-22 yaş aralığındaki öğrenciler arasında anlamlı $(p<.05)$ farklılık olduğu görülmektedir. 32 yaş ve üzeri öğrencilerin öz yönetimli öğrenme becerileri öz kontrol alt faktörü puan ortalamalarının, 18-22 yaş aralığındaki öğrencilere göre anlamlı derecede daha yüksek olduğu bulgusuna ulaşılmıştır.

Tablo 21

Öğrencilerin Yaş Değişkenine Göre Öz Yönetimli Öğrenme Becerileri Öz İzleme Alt Faktörüne İlişkin Dă̆llımları (ANOVA)

\begin{tabular}{cccccccccc}
\hline $\begin{array}{c}\text { Öğrenim } \\
\text { Düzeyi }\end{array}$ & $n$ & $\bar{X}$ & s.s & $\begin{array}{c}\text { Varyans } \\
\text { Kaynağı }\end{array}$ & $\begin{array}{c}\text { Kareler } \\
\text { Toplamı }\end{array}$ & s.d & $\begin{array}{c}\text { Kareler } \\
\text { Ort. }\end{array}$ & $F$ & $p^{*}$ \\
\hline $18-22$ & 33 & 19.00 & 5.16 & $\begin{array}{c}\text { Grup } \\
\text { Arası }\end{array}$ & 198.21 & 3 & 66.07 & 4.85 & $.003^{*}$ \\
$23-27$ & 37 & 20.86 & 3.09 & Grup İçi & 2000.71 & 147 & 13.61 & & \\
$28-32$ & 27 & 20.14 & 4.25 & Toplam & 2198.92 & 150 & & & \\
$32+$ & 54 & 22.01 & 2.49 & & & & & & \\
\hline Toplam & 151 & 20.74 & 3.82 & & & & & & \\
\hline$* p<0.05$ & & & & & & & &
\end{tabular}

Tablo 21'de öğrencilerin öz yönetimli öğrenme düzeyleri öz izleme alt faktörü puanının yaş değişkenine göre farklılaşıp farklılaşmadığı tek yönlü varyans analizi (ANOVA) testi ile incelenmiştir. Yapılan analiz sonucunda öz yönetimli öğrenme düzeyleri öz kontrol alt faktörü puanlarındaki fark istatistiksel olarak anlamlı bulunmuştur. Hangi gruplar arasında farklılaşma olduğunu ve grup ortalamasını ikili olarak farklı varyans yaklaşımı ile eş zamanlı karşılaştırmak için Tamhane Testi yapılmış analiz sonuçları Tablo 22'de gösterilmiştir. 
Tablo 22

Öğrencilerin Yaş Değişkenine Göre Tamamlayıcı İstatistiksel Analiz Sonuçları (Tamhane)

\begin{tabular}{cccccc}
\hline Tamhane & Yaş & Yaş & $\begin{array}{c}\text { Ortalamalar } \\
\text { Aras1 Fark }\end{array}$ & Std. Hata & $P^{*}$ \\
\hline \multirow{2}{*}{$23-22$} & $23-27$ & -1.86486 & 1.03306 & .381 \\
& $28-32$ & -1.14815 & 1.21665 & .924 \\
& $32+$ & $-3.01852^{*}$ & .96144 & .019 \\
& $18-22$ & 1.86486 & 1.03306 & .381 \\
& $28-32$ & .71672 & .96438 & .976 \\
& $32+$ & -1.15365 & .61168 & .326 \\
& $18-22$ & 1.14815 & 1.21665 & .924 \\
& $23-27$ & -.71672 & .96438 & .976 \\
& $32+$ & -1.87037 & .88722 & .228 \\
& $18-22$ & $3.01852^{*}$ & .96144 & .019 \\
& $23-27$ & 1.15365 & .61168 & .326 \\
& $28-32$ & 1.87037 & .88722 & .228 \\
\hline
\end{tabular}

${ }^{*} p<0.05$

Tablo 22 incelendiğinde, 32 yaş ve üzeri öğrencilerle, 18-22 yaş aralığındaki ögrrenciler arasında anlamlı $(p<.05)$ farklılık olduğu görülmektedir. 32 yaş ve üzeri öğrencilerin öz yönetimli öğrenme becerileri öz izleme alt faktörü puan ortalamalarının, 18-22 yaş aralığındaki öğrencilere göre anlamlı derecede daha yüksek olduğu bulgusuna ulaşılmıştır.

Tablo 23

Öğrencilerin Yaş Değişkenine Göre Öz Yönetimli Öğrenme Becerileri Özgüven Alt Faktörüne İlişkin Dă̆llımları (ANOVA)

\begin{tabular}{cccccccccc}
\hline $\begin{array}{c}\text { Öğrenim } \\
\text { Düzeyi }\end{array}$ & $n$ & $\overline{\mathrm{X}}$ & s.s & $\begin{array}{c}\text { Varyans } \\
\text { Kaynăg }\end{array}$ & $\begin{array}{c}\text { Kareler } \\
\text { Toplamı }\end{array}$ & s.d & $\begin{array}{c}\text { Kareler } \\
\text { Ort. }\end{array}$ & $F$ & $p^{*}$ \\
\hline $18-22$ & 33 & 16.66 & 3.91 & $\begin{array}{c}\text { Grup } \\
\text { Aras1 }\end{array}$ & 54.30 & 3 & 18.10 & 2.21 & .089 \\
$23-27$ & 37 & 17.00 & 2.52 & Grup İçi & 1200.09 & 147 & 8.16 & & \\
$28-32$ & 27 & 17.11 & 3.34 & Toplam & 1254.39 & 150 & & & \\
$32+$ & 54 & 18.12 & 1.89 & & & & & & \\
\hline Toplam & 151 & 17.35 & 2.89 & & & & & & \\
\hline$* 0<0.05$ & & & & & & &
\end{tabular}

Tablo 23'de öğrencilerin öz yönetimli öğrenme düzeyleri özgüven alt faktörü puanının yaş değişkenine göre farklılaşıp farklılaşmadığ 1 tek yönlü varyans analizi (ANOVA) testi ile incelenmiştir. Öğrencilerin öz yönetimli öğrenme düzeylerinin 
özgüven alt faktöründe anlamlı düzeyde farklılaşma olmadığ tespit edilmiştir. Anlamlı düzeyde farklılaşma olmasa da 32 yaş ve üzeri öğrencilerin $(\bar{X}=18.12), 28-32$ yaş aralığındaki öğrenciler $(\bar{X}=17.11), 23-27$ yaş aralığındaki öğrenciler $(\bar{X}=17.00)$ ve $18-22$ yaş aralığındaki öğrencilerin $(\overline{\mathrm{X}}=16.66)$ puanlarından daha yüksek olduğu görülmektedir.

Tablo 24

Öğrencilerin Genel Not Ortalamasına Göre Öz Yönetimli Öğrenme Becerileri Toplam Puanlarına İlişkin Dă̆llımları (ANOVA)

\begin{tabular}{|c|c|c|c|c|c|c|c|c|c|}
\hline $\begin{array}{c}\text { Genel Not } \\
\text { Ort. }\end{array}$ & $n$ & $\bar{x}$ & s.s & $\begin{array}{l}\text { Varyans } \\
\text { Kaynağı }\end{array}$ & $\begin{array}{l}\text { Kareler } \\
\text { Toplamı }\end{array}$ & s.d & $\begin{array}{c}\text { Kareler } \\
\text { Ort. }\end{array}$ & $F$ & $p^{*}$ \\
\hline$<2.00$ & 18 & 82.94 & 19.44 & $\begin{array}{l}\text { Grup } \\
\text { Aras1 }\end{array}$ & 2295.48 & 3 & 765.16 & 3.85 & $.011^{*}$ \\
\hline $2.00-3.00$ & 57 & 86.21 & 17.30 & Grup İçi & 29208.09 & 147 & 198.69 & & \\
\hline $3.00-3.50$ & 55 & 91.65 & 9.74 & Toplam & 31503.57 & 150 & & & \\
\hline $3.50-4.00$ & 21 & 95.19 & 6.67 & & & & & & \\
\hline Toplam & 151 & 89.05 & 14.49 & & & & & & \\
\hline
\end{tabular}

Tablo 24'te öğrencilerin öz yönetimli öğrenme düzeyleri toplam puanının genel not ortalaması değişkenine göre farklılaşıp farklılaşmadığı tek yönlü varyans analizi (ANOVA) testi ile incelenmiştir. Yapılan analiz sonucunda öz yönetimli öğrenme düzeyleri toplam puanlarındaki arasıdaki fark istatistiksel olarak anlamlı bulunmuştur. Hangi gruplar arasında farklılaşma olduğunu ve grup ortalamasını ikili olarak farklı varyans yaklaşımı ile eş zamanlı karşılaştırmak için Tamhane Testi yapıllmış analiz sonuçları Tablo 25'te gösterilmiştir. 
Tablo 25

Öğrencilerin Genel Not Ortalaması Değişkenine Göre Tamamlayıcı Ístatistiksel Analiz Sonuçları (Tamhane)

\begin{tabular}{|c|c|c|c|c|c|}
\hline Tamhane & $\begin{array}{l}\text { Genel Not } \\
\text { Ortalamas1 }\end{array}$ & Genel Not Ortalamas 1 & $\begin{array}{c}\text { Ortalamalar } \\
\text { Arası Fark }\end{array}$ & Std. Hata & $p^{*}$ \\
\hline & \multirow[t]{3}{*}{$<2.00$} & $2.00-3.00$ & -3.26608 & 5.12331 & .989 \\
\hline & & $3.00-3.50$ & -8.71010 & 4.76690 & .404 \\
\hline & & $3.50-4.00$ & -12.24603 & 4.80817 & .109 \\
\hline & \multirow[t]{3}{*}{$2.00-3.00$} & $<2.00$ & 3.26608 & 5.12331 & .989 \\
\hline & & $3.00-3.50$ & -5.44402 & 2.64168 & .228 \\
\hline & & $3.50-4.00$ & $-8.97995^{*}$ & 2.71546 & $.009 *$ \\
\hline & \multirow[t]{3}{*}{$3.00-3.50$} & $<2.00$ & 8.71010 & 4.76690 & .404 \\
\hline & & $2.00-3.00$ & 5.44402 & 2.64168 & .228 \\
\hline & & $3.50-4.00$ & -3.53593 & 1.96182 & .382 \\
\hline & \multirow[t]{3}{*}{$3.50-4.00$} & $<2.00$ & 12.24603 & 4.80817 & .109 \\
\hline & & $2.00-3.00$ & $8.97995^{*}$ & 2.71546 & $.009 *$ \\
\hline & & $3.00-3.50$ & 3.53593 & 1.96182 & .382 \\
\hline
\end{tabular}

${ }^{*} p<0.05$

Tablo 25 incelendiğinde, 3.50-4.00 genel not ortalamas1 olan öğrencilerin, 2.003.00 arasında genel not ortalaması olan öğrenciler arasında anlamlı $(p<.05)$ farklılık olduğu görülmektedir. 3.50-4.00 genel not ortalaması olan öğrencilerin öz yönetimli öğrenme becerileri puan ortalamalarının, 2.00-3.00 arasında genel not ortalaması olan öğrencilere göre anlamlı derecede daha yüksek olduğu bulgusuna ulaşılmıştır.

Tablo 26

Öğrencilerin Genel Not Ortalaması De ğişkenine Göre Öz Yönetimli Öğrenme Becerileri Güdüleme Alt Faktörüne İlişkin Dă̆llımları (ANOVA)

\begin{tabular}{|c|c|c|c|c|c|c|c|c|c|}
\hline $\begin{array}{l}\text { Genel } \\
\text { Not Ort. }\end{array}$ & $n$ & $\bar{x}$ & s.s & $\begin{array}{l}\text { Varyans } \\
\text { Kaynağ } 1\end{array}$ & $\begin{array}{c}\text { Kareler } \\
\text { Toplamı }\end{array}$ & s.d & $\begin{array}{l}\text { Kareler } \\
\text { Ort. }\end{array}$ & $F$ & $p^{*}$ \\
\hline$<2.00$ & 18 & 28.66 & 7.65 & $\begin{array}{l}\text { Grup } \\
\text { Aras1 }\end{array}$ & 303.43 & 3 & 101.14 & 4.13 & $.008 *$ \\
\hline $2.00-3.00$ & 57 & 30.47 & 6.04 & Grup İçi & 3594.15 & 147 & 24.450 & & \\
\hline $3.00-3.50$ & 55 & 32.20 & 2.93 & Toplam & 3897.58 & 150 & & & \\
\hline $3.50-4.00$ & 21 & 33.42 & 2.11 & & & & & & \\
\hline Toplam & 151 & 31.29 & 5.09 & & & & & & \\
\hline
\end{tabular}

Tablo 26'da öğrencilerin öz yönetimli öğrenme düzeyleri güdüleme alt faktörü puanının genel not ortalaması değişkenine göre farklılaşıp farklılaşmadığı tek yönlü varyans analizi (ANOVA) testi ile incelenmiştir. Yapılan analiz sonucunda öz yönetimli 
öğrenme düzeyleri güdüleme alt faktörü puanlarındaki fark istatistiksel olarak anlamlı bulunmuştur. Hangi gruplar arasında farklılaşma olduğunu ve grup ortalamasını ikili olarak farklı varyans yaklaşımı ile eş zamanlı karşılaştırmak için Tamhane Testi yapılmış analiz sonuçları Tablo 27'de gösterilmiştir.

Tablo 27

Öğrencilerin Genel Not Ortalaması Değişkenine Göre Tamamlayıcı İstatistiksel Analiz Sonuçları (Tamhane)

\begin{tabular}{|c|c|c|c|c|c|}
\hline Tamhane & Genel Not Ortalamas1 & Genel Not Ortalaması & $\begin{array}{c}\text { Ortalamalar } \\
\text { Arası Fark }\end{array}$ & Std. Hata & $p^{*}$ \\
\hline \multirow{3}{*}{\multicolumn{2}{|c|}{$<2.00$}} & $2.00-3.00$ & -1.80702 & 1.97366 & .937 \\
\hline & & $3.00-3.50$ & -3.53333 & 1.84700 & .358 \\
\hline & & $3.50-4.00$ & -4.76190 & 1.86203 & .110 \\
\hline \multirow{3}{*}{\multicolumn{2}{|c|}{$2.00-3.00$}} & $<2.00$ & 1.80702 & 1.97366 & .937 \\
\hline & & $3.00-3.50$ & -1.72632 & .89270 & .295 \\
\hline & & $3.50-4.00$ & $-2.95489 *$ & .92340 & $.012 *$ \\
\hline \multirow{3}{*}{\multicolumn{2}{|c|}{$3.00-3.50$}} & $<2.00$ & 3.53333 & 1.84700 & .358 \\
\hline & & $2.00-3.00$ & 1.72632 & .89270 & .295 \\
\hline & & $3.50-4.00$ & -1.22857 & .60724 & .257 \\
\hline & $3.50-4.00$ & $<2.00$ & 4.76190 & 1.86203 & .110 \\
\hline & & $2.00-3.00$ & $2.95489^{*}$ & .92340 & $.012^{*}$ \\
\hline & & $3.00-3.50$ & 1.22857 & .60724 & .257 \\
\hline
\end{tabular}

Tablo 27 incelendiğinde, 3.50-4.00 genel not ortalaması olan öğrencilerle, 2.003.00 arasında genel not ortalaması olan öğrenciler arasında anlamlı $(p<.05)$ farklılık olduğu görülmektedir. 3.50-4.00 genel not ortalaması olan öğrencilerin öz yönetimli öğrenme becerileri puan ortalamalarının, 2.00-3.00 arasında genel not ortalaması olan öğrencilere göre anlamlı derecede daha yüksek olduğu bulgusuna ulaşılmıştır. 
Tablo 28

Öğrencilerin Genel Not Ortalaması Değişkenine Göre Öz Yönetimli Öğrenme Becerileri Öz Kontrol Alt Faktörüne İlişkin Dağılımları (ANOVA)

\begin{tabular}{cccccccccc}
\hline $\begin{array}{c}\text { Genel } \\
\text { Not Ort. }\end{array}$ & $n$ & $\overline{\mathrm{X}}$ & s.s & $\begin{array}{c}\text { Varyans } \\
\text { Kaynağı }\end{array}$ & $\begin{array}{c}\text { Kareler } \\
\text { Toplamı }\end{array}$ & s.d & $\begin{array}{c}\text { Kareler } \\
\text { Ort. }\end{array}$ & $F$ & $p$ \\
\hline 2.00 & 18 & 18.11 & 4.84 & $\begin{array}{c}\text { Grup } \\
\text { Arası }\end{array}$ & 182.55 & 3 & 60.85 & 3.64 & $.014 *$ \\
$2.00-$ & 57 & 18.84 & 4.86 & Grup İçi & 2457.21 & 147 & 16.71 & \\
3.00 & & & & & & & & \\
$3.00-$ & 55 & 20.27 & 3.30 & Toplam & 2639.77 & 150 & & \\
3.50 & & & & & & & & \\
$3.50-$ & 21 & 21.61 & 2.65 & & & & &
\end{tabular}

Tablo 29

Öğrencilerin Genel Not Ortalamasına Göre Tamamlayıcı Ístatistiksel Analiz Sonuçları (Tamhane)

\begin{tabular}{|c|c|c|c|c|c|}
\hline Tamhane & Genel Not Ortalaması & Genel Not Ortalaması & $\begin{array}{c}\text { Ortalamalar } \\
\text { Arası Fark }\end{array}$ & Std. Hata & $p^{*}$ \\
\hline \multirow{3}{*}{\multicolumn{2}{|c|}{$<2.00$}} & $2.00-3.00$ & -.73099 & 1.31239 & .995 \\
\hline & & $3.00-3.50$ & -2.16162 & 1.22668 & .438 \\
\hline & & $3.50-4.00$ & -3.50794 & 1.28143 & .065 \\
\hline \multirow{3}{*}{\multicolumn{2}{|c|}{$2.00-3.00$}} & $<2.00$ & .73099 & 1.31239 & .995 \\
\hline & & $3.00-3.50$ & -1.43062 & .78371 & .357 \\
\hline & & $3.50-4.00$ & $-2.77694^{*}$ & .86690 & .013 \\
\hline \multirow{3}{*}{\multicolumn{2}{|c|}{$3.00-3.50$}} & $<2.00$ & 2.16162 & 1.22668 & .438 \\
\hline & & $2.00-3.00$ & 1.43062 & .78371 & .357 \\
\hline & & $3.50-4.00$ & -1.34632 & .73068 & .361 \\
\hline & $3.50-4.00$ & $<2.00$ & 3.50794 & 1.28143 & .065 \\
\hline & & $2.00-3.00$ & $2.77694^{*}$ & .86690 & .013 \\
\hline & & $3.00-3.50$ & 1.34632 & .73068 & .361 \\
\hline
\end{tabular}

Tablo 28'de öğrencilerin öz yönetimli öğrenme düzeyleri öz kontrol alt faktörü puanının yaş değişkenine göre farklılaşıp farklılaşmadığı tek yönlü varyans analizi (ANOVA) testi ile incelenmiştir. Yapılan analiz sonucunda öz yönetimli öğrenme düzeyleri öz kontrol alt faktörü puanlarındaki fark istatistiksel olarak anlamlı bulunmuştur. Hangi gruplar arasında farklılaşma olduğunu ve grup ortalamasını ikili olarak farklı varyans yaklaşımı ile eş zamanlı karşılaştırmak için Tamhane Testi yapılmış analiz sonuçları Tablo 29'da gösterilmiştir. 
Tablo 29 incelendiğinde, 3.50-4.00 genel not ortalamas1 olan öğrencilerle, 2.003.00 arasında genel not ortalaması olan öğrenciler arasında anlamlı $(p<.05)$ farklılık olduğu görülmektedir. 3.50-4.00 genel not ortalaması olan öğrencilerin öz yönetimli öğrenme becerileri puan ortalamalarının, 2.00-3.00 arasında genel not ortalaması olan öğrencilere göre anlamlı derecede daha yüksek olduğu bulgusuna ulaşılmıştır.

Tablo 30

Ögrencilerin Genel Not Ortalamast Değişkenine Göre Öz Yönetimli Öğrenme Becerileri Öz İleme Alt Faktörüne İlişkin Dağılımları (ANOVA)

\begin{tabular}{|c|c|c|c|c|c|c|c|c|c|}
\hline $\begin{array}{c}\text { Genel } \\
\text { Not } \\
\text { Ort. }\end{array}$ & $n$ & $\bar{x}$ & s.s & $\begin{array}{l}\text { Varyans } \\
\text { Kaynağı }\end{array}$ & $\begin{array}{l}\text { Kareler } \\
\text { Toplamı }\end{array}$ & s.d & $\begin{array}{c}\text { Kareler } \\
\text { Ort. }\end{array}$ & $F$ & $p^{*}$ \\
\hline$<2.00$ & 18 & 18.55 & 4.63 & Grup Aras1 & 203.44 & 3 & 67.81 & 3.64 & $.003^{*}$ \\
\hline $\begin{array}{c}2.00- \\
3.00\end{array}$ & 57 & 20.05 & 4.40 & Grup İçi & 1995.48 & 147 & 13.57 & & \\
\hline $\begin{array}{c}3.00- \\
3.50\end{array}$ & 55 & 21.56 & 2.96 & Toplam & 2198.92 & 150 & & & \\
\hline $\begin{array}{c}3.50- \\
4.00\end{array}$ & 21 & 22.33 & 1.87 & & & & & & \\
\hline Toplam & 151 & 20.74 & 3.82 & & & & & & \\
\hline
\end{tabular}

Tablo 30’da öğrencilerin öz yönetimli öğrenme düzeyleri öz izleme alt faktörü puanının yaş değişkenine göre farklılaşıp farklılaşmadığı tek yönlü varyans analizi (ANOVA) testi ile incelenmiştir. Yapılan analiz sonucunda öz yönetimli öğrenme düzeyleri öz izleme alt faktörü puanlarındaki fark istatistiksel olarak anlamlı bulunmuştur. Hangi gruplar arasında farklılaşma olduğunu ve grup ortalamasını ikili olarak farklı varyans yaklaşımı ile eş zamanlı karşıllaştırmak için Tamhane Testi yapılmış analiz sonuçları Tablo 31 'de gösterilmiştir. 


\section{Tablo 31}

Öğrencilerin Genel Not Ortalaması Değişkenine Göre Tamamlayıcı Ístatistiksel Analiz Sonuçları (Tamhane)

\begin{tabular}{|c|c|c|c|c|c|}
\hline Tamhane & Genel Not Ortalaması & Genel Not Ortalaması & $\begin{array}{c}\text { Ortalamalar } \\
\text { Arası Fark }\end{array}$ & Std. Hata & $p^{*}$ \\
\hline \multirow{3}{*}{\multicolumn{2}{|c|}{$<2.00$}} & $2.00-3.00$ & -1.49708 & 1.23728 & .802 \\
\hline & & $3.00-3.50$ & -3.00808 & 1.16237 & .097 \\
\hline & & $3.50-4.00$ & $-3.77778^{*}$ & 1.16587 & .023 \\
\hline \multirow{3}{*}{\multicolumn{2}{|c|}{$2.00-3.00$}} & $<2.00$ & 1.49708 & 1.23728 & .802 \\
\hline & & $3.00-3.50$ & -1.51100 & .70709 & .193 \\
\hline & & $3.50-4.00$ & $-2.28070^{*}$ & .71282 & .012 \\
\hline \multirow{3}{*}{\multicolumn{2}{|c|}{$3.00-3.50$}} & $<2.00$ & 3.00808 & 1.16237 & .097 \\
\hline & & $2.00-3.00$ & 1.51100 & .70709 & .193 \\
\hline & & $3.50-4.00$ & -.76970 & .57303 & .706 \\
\hline \multirow{3}{*}{\multicolumn{2}{|c|}{$3.50-4.00$}} & $<2.00$ & $3.77778 *$ & 1.16587 & .023 \\
\hline & & $2.00-3.00$ & $2.28070^{*}$ & .71282 & .012 \\
\hline & & $3.00-3.50$ & .76970 & .57303 & .802 \\
\hline
\end{tabular}

${ }^{*} p<0.05$

Tablo 31 incelendiğinde, 3.50-4.00 genel not ortalaması olan öğrencilerle, 2.003.00 arasında genel not ortalaması olan öğrenciler arasında anlamlı $(p<.05)$ farklılık olduğu görülmektedir. 3.50-4.00 genel not ortalaması olan öğrencilerin öz yönetimli öğrenme becerileri puan ortalamalarının, 2.00-3.00 arasında genel not ortalaması olan öğrencilere göre anlamlı derecede daha yüksek olduğu bulgusuna ulaşılmıştır.

Tablo 32

Öğrencilerin Genel Not Ortalaması Değişkenine Göre Öz Yönetimli Öğrenme Becerileri Özgüven Alt Faktörüne İlişkin Dağılımları (ANOVA)

\begin{tabular}{|c|c|c|c|c|c|c|c|c|c|}
\hline $\begin{array}{c}\text { Genel } \\
\text { Not Ort. }\end{array}$ & $n$ & $\bar{x}$ & S.S & $\begin{array}{l}\text { Varyans } \\
\text { Kaynağı }\end{array}$ & $\begin{array}{l}\text { Kareler } \\
\text { Toplamı }\end{array}$ & s.d & $\begin{array}{c}\text { Kareler } \\
\text { Ort. }\end{array}$ & $F$ & $p^{*}$ \\
\hline$<2.00$ & 18 & 17.61 & 3.79 & $\begin{array}{l}\text { Grup } \\
\text { Aras1 }\end{array}$ & 24.32 & 3 & 8.10 & 3.64 & .969 \\
\hline $\begin{array}{c}2.00- \\
3.00\end{array}$ & 57 & 16.84 & 3.33 & Grup İçi & 1230.07 & 147 & 8.36 & & \\
\hline $\begin{array}{l}3.00- \\
3.50\end{array}$ & 55 & 17.61 & 2.30 & Toplam & 1254.39 & 150 & & & \\
\hline $\begin{array}{l}3.50- \\
4.00\end{array}$ & 21 & 17.80 & 1.96 & & & & & & \\
\hline Toplam & 151 & 17.35 & 2.89 & & & & & & \\
\hline
\end{tabular}


Tablo 32'de öğrencilerin öz yönetimli öğrenme düzeyleri özgüven alt faktörü puanının genel not ortalaması değişkenine göre farklılaşıp farklılaşmadığ varyans analizi (ANOVA) testi ile incelenmiştir. Öğrencilerin öz yönetimli öğrenme düzeylerinin özgüven alt faktöründe anlamlı düzeyde farklılaşma olmadığı tespit edilmiştir. Anlamlı düzeyde farklılaşma olmasa da genel not ortalaması 3.50-4.00 olan öğrencilerin ( $\bar{X}=17.80)$, genel not ortalamas1 3.00-3.50 olan öğrencilerin $(\bar{X}=17.61)$, genel not ortalamas1 2.00 'dan düşük olan öğrencilerin $(\bar{X}=17.61)$ ve genel not ortalamas1 2.00-3.00 olan öğrencilerin ( $\bar{X}=16.84)$ puanlarından daha yüksek olduğu görülmektedir.

\section{Sonuç ve Tartışma}

Araştırmada uzaktan eğitim öğrencilerinin öz yönetimli öğrenme becerileri çeşitli değişkenler açısından incelenmiştir. Araştırma sonuçlarına göre uzaktan eğitim ile öğrenim gören öğrencilerin öz yönetimli öğrenme becerileri ölçek orta puanının üzerinde bulunmuştur. Ölçeğin alt boyutları olan güdülenme, öz-izleme, öz-kontrol ve özgüven boyutlarına ait puanlarında kendi orta puanlarının üzerinde olduğu sonucuna ulaşılmıştır.

Cinsiyet değişkenine göre öğrencilerin öz yönetimli öğrenme düzeylerinin güdüleme alt faktöründe anlamlı düzeyde farklılaşma olduğu, diğer alt faktör ve ölçeğin tamamında anlamlı bir farklılık olmadığı görülmektedir. Anlamlı bir farklılaşma olmasa da kadın öğrencilerin öz yönetimli öğrenme düzeylerinin, erkek öğrencilerin öz yönetimli öğrenme düzeylerinden daha yüksek olduğu, kadın öğrencilerin, erkek öğrencilere isteklendirmelerinin, kendini kontrol etme düzeylerinin, kendi performans değerlendirmesinin ve özgüvenlerinin daha yüksek olduğu sonucuna ulaşılmıştır. Literatür incelendiğinde bu araştırmada çıkan bulgu sonucunu destekleyen çalışmaların (Aşkın, 2015; Britner \& Pajares, 2006; Ekici, 2005; Yaman, Koray \& Altunçekiç, 2004) olduğu görülmektedir. Bazı araştırmalarda (Akbaş \& Çelikkaleli, 2006; Arsal, 2006; Çakıroğlu, Çakıroğlu \& Bone, 2005; Özçelik \& Kurt, 2007) ise öğrencilerin öz-yeterlik algılarında cinsiyete göre istatistiksel olarak anlamlı bir farklılık olmadığı tespit edilmiştir. Araştırma sonuçlarındaki bu farklılığın araştırmaların niteliklerinden, kadın öğrencilerin, erkek öğrencilere göre ders disiplinlerinin daha yüksek olması ve ders motivasyonlarından kaynaklı olduğu söylenebilir.

Üniversite değişkenine göre öğrencilerin öz yönetimli öğrenme düzeylerinin güdüleme alt faktöründe anlamlı farklılaşma olduğu, ölçeğin tamamında ve diğer alt faktörlerde anlamlı bir farklılık olmadığı görülmektedir. Anlamlı bir farklılaşma olmasa da İstanbul Üniversitesi, Gazi Üniversitesi ve Afyon Kocatepe Üniversitesi öğrencilerinin öz yönetimli öğrenme becerilerinin diğer üniversite öğrencilerinin öz yönetimli öğrenme becerilerinden daha yüksek olduğu sonucuna ulaşılmıştır. Öğrencilerin güdüleme (isteklendirme, motivasyon) durumlarının sirayla İstanbul Üniversitesi, Muğla Sitkı Koçman Üniversitesi, Gazi Üniversitesi ve Afyon Kocatepe Üniversitesi öğrencilerinden daha yüksek olduğu sonucu ortaya çıkmıştır. Öz yönetimli öğrenme sürecinin gerekliliklerinden olan güdülenme, üst bilişsel stratejiler, öz kontrol, kendine güven gibi yapılar (Schunk,1995; Downing,2009), öğrencilerin kendi tutum ve özellikleriene göre değişmektedir. Sıralamanın bu şekilde olmasında öğrencilerin ders ve öğrenim süreçlerine aktif katılım sağlaması, akademik başarı durumlarının daha yüksek olması ve özverili olma durumlarıdan kaynaklı olduğu söylenebilir. Çünkü öz yönetimli öğrenme sürecinde, bireyin belirlemiş olduğu hedefe ulaşabilmesi için 
karşılaştığ1 zorluklar karşısında içsel motivasyonu sağlayabilmesi ve öğrenme kapasitesine inanıp öğrenmek için çaba göstermesi ve ısrarlı olması gerekmektedir (Karataş \& Başbay, 2014). Öz-kontrol düzeyinde İstanbul Üniversitesi, Afyon Kocatepe Üniversitesi ve Gazi Üniversitesi öğrencilerinin, öz-izleme düzeyinde Afyon Kocatepe Üniversitesi, İstanbul Üniversitesi ve Gazi Üniversitesi öğrencilerinin, özgüven düzeylerinde İstanbul Üniversitesi, Muğla Sitkı Koçman Üniversitesi ve Gazi Üniversitesi öğrencilerinin öz yönetimli öğrenme yeteneklerinin daha yüksek olduğu sonucuna ulaşılmıştır.

Öğrencilerin lisansüstü çalışma yapma isteklerine göre öz yönetimli öğrenme düzeylerinde güdüleme alt faktöründe anlamlı düzeyde farklılaşma olduğu, diğer alt faktör ve ölçeğin tamamında anlamlı bir farklılık olmadığ 1 görülmektedir. Anlamlı bir farklılaşma olmasa da lisansüstü çalışma yapmak isteyen öğrencilerin, lisansüstü çalışma yapmak istemeyen öğrencilere göre öz yönetimli öğrenme düzeylerinin daha yüksek olduğu sonuçlarına ulaşılmıştır. $\mathrm{Bu}$ öğrencilerin kendi performans değerlendirmelerinin ve özgüvenlerinin daha yüksek olduğu söylenebilir. Elde edilen bulgu sonucunu Aşkın (2015) tarafından yapılan çalışma sonucu desteklemektedir. Sonucun bu şekilde çıkmasında lisansüstü çalışma yapma isteği olan öğrencilerin, lisansüstü çalışma yapma isteği olmayan öğrencilere göre ders disiplin ve ders isteklendirmelerinin daha yüksek olmasından kaynaklı olduğu söylenebilir.

Öğrenim düzeyi değişkenine göre öğrencilerin öz yönetimli öğrenme düzeylerinde ölçeğin tamamında ve tüm alt faktörlerde anlamlı bir farklılık olmadığı görülmektedir. Anlamlı bir farklılaşma olmasa da yüksek lisans öğrencilerinin, önlisans ve lisans öğrencilerine göre öz yönetimli öğrenme düzeylerinin daha yüksek olduğu, yüksek lisans öğrencilerinin güdüleme (isteklendirme, motivasyon) durumlarının, lisans ve önlisans öğrencilerinden daha yüksek olduğu, öz-kontrol düzeyinde yüksek lisans öğrencilerinin, önlisans ve lisans öğrencilerine göre, öz-izleme düzeyinde yüksek lisans öğrencilerinin, önlisans ve lisans öğrencilerine göre, özgüven düzeylerinde lisans öğrencilerinin, önlisans ve yüksek lisans öğrencilerine göre öz yönetimli öğrenme becerilerinin daha yüksek olduğu sonucuna ulaşılmıştır.

Yaş değişkenine göre öğrencilerin öz yönetimli öğrenme düzeylerinde ölçeğin tamamında ve özgüven alt faktörü haricinde tüm alt faktörlerde anlamlı bir farklılık olduğu görülmektedir. Ölçeğin tamamında 32 yaş ve üzeri öğrencilerin öz yönetimli öğrenme becerileri düzeylerinin, 18-22 yaş ve 23-27 yaş aralığındaki öğrencilere göre daha yüksek olduğu bulgusuna ulaşılmıştır. Alt faktörler bazında güdüleme alt faktöründe 32 yaş ve üzeri öğrencilerin, 18-22 yaş ve 23-27 yaş aralığındaki öğrencilere göre, öz-kontrol alt faktöründe 32 yaş ve üzeri öğrencilerin, 18-22 yaş aralığındaki öğrencilere göre, öz-izleme alt faktöründe 32 yaş ve üzeri öğrencilerin, 18-22 yaş aralığındaki öğrencilere göre öz yönetimli öğrenme beceri düzeylerinin daha yüksek olduğu, anlamlı bir farklılık olmasa da özgüven alt faktöründe 32 yaş ve üzeri öğrencilerin, 28-32, 23-27 ve 18-22 yaş aralığındaki öğrencilere göre öz yönetimli öğrenme beceri düzeylerinin daha yüksek olduğu sonucuna ulaşılmıştır. Bulgu sonucuna göre yaş ortalaması yüksek olan öğrencilerin, yaş ortalaması düşük olan öğrencilere göre öz yönetimli öğrenim süreçlerini daha iyi yönettiği görülmektedir. Bulgu sonucunun bu şekilde çıkmasında yaş ortalaması daha yüksek olan öğrencilerin, bir şeyin nedenini bilme ihtiyacı duyma, araştırma yeteneğine güvenme, karar vermeden önce bilgi toplama, amaç belirleme, öğrenmelerini planlama ve yönetme, yeteneklerine 
güvenme, sorgulama, araştırma gibi öz yönetimli öğrenmeye ilişkin beceri, eğilim, yetenek ve kişisel özelliklere (Ulusoy \& Karakuş, 2018) ve zamanla tecrübe ederek daha iyi yönetsel becerilere sahip olmasından kaynaklı olduğu söylenebilir.

Genel not ortalaması değişkenine göre öğrencilerin öz yönetimli öğrenme düzeylerinde ölçeğin tamamında ve özgüven alt faktörü haricinde tüm alt faktörlerde anlamlı bir farklılık olduğu görülmektedir. Ölçeğin tamamında 3.50-4.00 genel not ortalaması olan öğrencilerin öz yönetimli öğrenme becerileri düzeylerinin, 2.00-3.00 arasında genel not ortalaması olan öğrencilere göre daha yüksek olduğu bulgusuna ulaşılmıştır. Alt faktörler bazında güdüleme alt faktöründe 3.50-4.00 genel not ortalaması olan öğrencilerin, 2.00-3.00 arasında genel not ortalaması olan öğrencilere göre, öz-kontrol alt faktöründe 3.50-4.00 genel not ortalaması olan öğrencilerin, 2.003.00 arasında genel not ortalaması olan öğrencilere göre, öz-izleme alt faktöründe 3.504.00 genel not ortalaması olan öğrencilerin, 2.00-3.00 arasında genel not ortalaması olan öğrencilere göre öz yönetimli öğrenme beceri düzeylerinin daha yüksek olduğu, anlamlı bir farklılık olmasa da özgüven alt faktöründe genel not ortalamas1 3.50-4.00 olan öğrencilerin, genel not ortalamas1 3.00-3.50 ve genel not ortalamas1 2.00-3.00 olan öğrencilere göre öz yönetimli öğrenme beceri düzeylerinin daha yüksek olduğu sonucuna ulaşılmıştır. Bu bulgu sonucunu alanda yapılan bazı çalışmalar (Alkan, 2012; Aydede \& Kesercioğlu, 2012; Chou, 2012; Haron, 2003; Hsu \& Shiue, 2005; Khan vd.,2012; Karataş \& Başbay, 2014; Reio, 2004; Sarmasoğlu, 2009; Shinkareva \& Benson, 2007) desteklemektedir. Akademik başarısı yüksek olan öğrencilerin öz yönetimli öğrenme süreçlerinde daha aktif ve başarılı olduğu görülmektedir. Akademik başarısı yüksek bireyler öğrendiklerini yeni durumlara daha iyi transfer edebilen, daha gelişmiş ve etkili öz düzenleyici öğrenme stratejileri kullanabilen ve başarı yönetimli olup iç disiplinli, sorumluluk sahibi, dikkatli, başarma duygusu yüksek, düzenli ve kararlı kimselerdir (Costa \& McCrae, 1995; Doğanay \& Demir, 2011). Bulgu alanda yapılan bazı çalışmalar ilede farklı1ık göstermektedir (Deyo vd.,2011; Yenilmez \& Şan, 2008). Bunun nedeni olarak öğrencilerin ders süreçlerinde aktif takip, katılım ve yönetimlerini gerçekleştirememelerinden kaynaklı olduğu söylenebilir. Bireyin öz yönetimli öğrenmeye hazırbulunuşluğunun sağlanması ve öğrenmeyi öğrenme becerisini edinebilmesi için belli bir alanda akademik alt yapıya sahip olması gerekmektedir (Karataş \& Başbay, 2014).

\section{Öneriler}

Elde edilen bulgulara dayalı olarak uzaktan eğitim öğrencilerinin öz yönetimli öğrenme düzeylerinin ders istek ve başarılarına etki edeceği düşüldüğünde öz-yönetimli öğrenme ile ilgili çalışmalar büyük önem arz etmektedir. Buna bağlı olarak daha sonra yapılacak araştırmalara ve var olan uygulamalara yönelik şu önerilere yer verilebilir.

1. Öz-yönetimli öğrenme ile ilgili çalışmalar yapılabilir ve alana katkı sağlayabilir.

2. Çalışma örgün eğitimle eğitim gören yükseköğrenim ve lise öğrencilerine uygulanarak sonuçları karşılaştırılabilir ve alana katkı sağlayabilir.

3. Çalışma farklı demografik gruplar üzerinde uygulanarak öz-yönetimli öğrenme ile ilgili yapılacak çalışmalar alana katkı sağlayabilir.

4. $\mathrm{Bu}$ alanda yapılacak çalışmalarda durumun tespiti için derinlemesine nitel çalışmalar yapılabilir. 


\section{Summary}

Purpose and Significance: For a quality education, it is important for distance education students to determine personal learning goals and plans and to manage these processes. When the related literature is examined, it is seen that the studies are mostly sourced from abroad and Turkish studies in this area is limited. Turkey is in a process of change and distance education students should obtain self-regulated learning skills. Because of all these facts, this research is highly important. This research can contribute to the related literature in Turkey and it can set an example for future researchers in the area.

Method: In this study, it is aimed to examine self-directed learning skills of distance education students. This is a descriptive study and based on the screening model. Screening models are research approaches designed in order to describe a past or present situation as it is. There are a total of 151 students in the study group; Afyon Kocatepe University (Computer Programming and Management of Internet and Information Technologies MA) Muğla Sıtkı Koçman University (Master of Science without thesis Economics and Finance, Business, Computer Programming), Anadolu University (Child Development, Business Administration), Sakarya University (Mechatronics, Electronic Technologies, Computer Programming) Istanbul University (Sociology, Industrial Engineering), Gazi University (Information Systems), Süleyman Demirel University (Information Management, Medical Documentation and Secretary, Computer Programming) and Karabük University (Child Development) students having distance education are the participants of this study. The data collection tool used in the study is developed by Aşkın (2015) within the scope of doctoral dissertation. "Selfdirected Learning Skills Scale" is used for collecting data and "Personal Information Form" is used for determining the personal characteristics of participants. Self-directed Learning Skills Scale is 5-points likert type and involves 21 items. Participants are graded as: 1 (Never), 2 (Rarely), 3 (Sometimes), 4 (Generally), 5 (Always). Minimum score as a result of the survey is 21 while maximum score is 105 . Alpha reliability coefficient of the scale is .895. In the Personal Information Form; information about participants' gender, university, willingness to have postgraduate education, education level, age and GPA is obtained. Survey data obtained from research is analyzed in SPSS 20.0 program. In order to determine the normality of the distribution, KolmogrovSmirnov test is conducted. At the end of the analyses, it is determined that the data are normally distributed. This is why, Independent groups t-test, one of the parametric tests, and One-Way Anova analyses are used in order to analyze data. At the end of One-Way Anova analysis, Tamhane test is used in the cases with meaningful difference as group variances weren't equal.

Results and Discussion: According research results, self-directed learning skills of distance education students are above the mid-point of the scale. It is determined that points of scale's motivation, self-monitoring, self-control and self-confidence subdimensions are above mid-point.

It is seen that in terms of sex variable, there is not a meaningful difference in motivation of students, which is self-directed learning level sub-factor. On the other hand, there 
isn't a meaningful difference in the other sub-factors and in the complete scale in terms of sex variable. It is observed that female students' self-directed learning levels are higher than male students; female students' self-motivation, self-control level, selfperformance evaluation and self-confidence levels are higher than male students. These findings of the research are in line with the study results of Asskın (2015). It can be said that higher lesson discipline and motivation of female students are the causes of these results.

It is observed that while there is a meaningful difference in students' self-directed learning levels in terms of sex variable, there is not a meaningful difference in other sub-factors and in the complete scale. It is observed that female students' motivation, self-control, self-performance evaluation and self-confidence are higher than male students. These findings of the research are in line with the study results of Asskin (2015). It can be said that higher lesson discipline and motivation of female students are the causes of these results.

It is seen that in university variable, there is a difference in terms of motivation in selfdirected learning levels of students; on the other hand, there is not meaningful difference in the other sub-factors and in the complete scale. Although there is not a meaningful difference, it is observed that İstanbul University, Gazi University and Afyon Kocatepe University students' self-directed learning skills are higher than the students in other universities. It is determined that there is meaningful difference in terms of self-directed learning level motivation sub-factor according to willingness for postgraduate study; there is not meaningful difference in other sub-factors and in the complete scale. Although there is not meaningful difference, it is observed that students who are willing to have postgraduate degree have higher self-directed learning levels, have higher motivation, self-control, self-evaluation and self-confidence levels. This result is supported by the study made by Aşkın (2015). It can be said that higher lesson discipline and motivation of students who are willing to have postgraduate education are the causes of this result.

It is determined that there is not a meaningful difference in self-directed learning levels in terms of education level variable in the complete scale and all of the sub-factors. Although there is not meaningful difference, it is determined that postgraduate students' self-directed learning levels are higher than associate and undergraduate students; on the other hand, motivation, self-control, self-monitoring levels of postgraduate students are higher than associate and undergraduate students. It is seen that undergraduate students' self-confidence levels are higher than associate and postgraduate students.

It is observed that there is a meaningful difference in students' self-directed learning levels in terms of age variable in the complete scale and in all of the sub-factors except self-confidence. In the complete scale, it is determined that students above the age 31 have higher self-directed learning skill levels than students between 18-22 and 23-27 ages. In motivation sub-factor, students above the age 31 have higher levels than students between 18-22 and 23-27 ages. In self-control and self-monitoring sub-factors, students above the age 31 have higher levels than students between 18-22 ages. Although it is not a meaningful difference, it is seen that in terms of self-confidence, students above the age 31 have higher self-directed learning skill levels than students between 18-22 and 23-27 ages. 
It is determined that there is meaningful difference in self-directed learning skill levels of students according to grade point average in the complete scale and in all of the subfactors except self-confidence. It is found that students with 3.50-4.00 GPA have higher self-directed learning skills than students with 2.00-3.00 GPA. In terms of sub-factors, in motivation sub-factor, it is determined that students with 3.50-4.00 GPA have higher self-directed learning skills in self-control, self-monitoring levels than students with 2.00-3.00 GPA. Although it is not a meaningful difference, it is seen that students with 3.50-4.00 GPA have lower self-confidence levels than students with 2.00-3.00 GPA. On the other hand, it is observed that students with 3.50-4.00 GPA have higher self-directed learning skills than students with 2.00-3.00 GPA. 


\section{Kaynakça}

Akbaş, A., \& Çelikkaleli, Ö. (2006). Sınıf öğretmeni adaylarının fen öğretimi özyeterlik inançlarının cinsiyet, öğrenim türü ve üniversitelerine göre incelenmesi. Mersin Üniversitesi Ĕ̆itim Fakültesi Dergisi, 2(1), 98-110.

Alkan, F. (2012). Kendi kendine öğrenmenin kimya laboratuvarında ögrenci başarısına, ögrenme hazırbulunuşluğuna, laboratuvar becerilerine yönelik tutumuna ve endişesine etkisi (Yayımlanmamış Doktora Tezi). Hacettepe Üniversitesi Fen Bilimleri Enstitüsü, Ankara.

Arsal, Z. (2006, April). Self-efficacy beliefs of teacher candidates on using a computer in teaching. Paper presented at 6th International Educational Technologies Conference, 19-21 April, Eastern Mediterranean University, North Cyprus.

Aşkın, İ. (2015). Üniversite öğrencilerinin öz-yönetimli öğrenme becerilerinin incelenmesi (Yayımlanmamış Doktora Tezi). Hacettepe Üniversitesi Eğitim Bilimleri Enstitüsü, Ankara.

Aydede, M. N., \& Kesercioğlu, T. (2012). Aktif öğrenme uygulamalarının öğrencilerin kendi kendine öğrenme becerilerine etkisi. Hacettepe Üniversitesi Ĕgitim Fakültesi Dergisi, 43(43), 37-49.

Britner, S. L., \& Pajares, F. (2006). Sources of science self-efficacy beliefs of middle school students. Journal of Research in Science Teaching: The Official Journal of the National Association for Research in Science Teaching, 43(5), 485-499.

Brockett, R. G., \& Hiemstra, R. (1991). Self-direction in adult learning: Perspectives on theory, research and practice. Routledge.

Brookfield, S. D. (2009). Self-directed learning. In Maclean, R. \& Wilson, D. (Eds), International handbook of education for the changing world of work (pp. 26152627). New York: Springer Science and Business Media.

Brooks, D. W. (1997). Web teaching: A guide to designing interactive teaching for the World Wide Web. New York, NY: Plenum.

Büyüköztürk, Ş. (2012). Sosyal bilimler için veri analizi el kitabı. (17. Basım). Pegem Akademi Yayınları: Ankara.

Çakıroğlu, J., Çakıroğlu, E., \& Boone, W. J. (2005). Pre-Service teacher self-efficacy beliefs regarding science teaching: a comparison of pre-service teachers in Turkey and the USA. Science Educator, 14(1), 31-40.

Chou, P. N. (2012). The relationship between engineering students' self-directed learning abilities and online learning performances: A pilot study. Contemporary Issues in Education Research, 5(1), 33-38.

Costa, P.T.\& McCrae, R.R. (1995). Domains and facets: Hierarchical personality assessment using the revised neo personality inventory. Journal of Personality Assessment, 64(1), 21-50.

Deyo, Z. M., Huynh, D., Rochester, C., Sturpe, D. A., \& Kiser, K. (2011). Readiness for self-directed learning and academic performance in an abilities laboratory course. American Journal of Pharmaceutical Education, 75(2), 25.

Doğanay, A. \& Demir Ö. (2011). Akademik başarısı düşük ve yüksek öğretmen adaylarının ders çalışma sırasında bilişsel farkındalık becerilerini kullanma 
düzeylerinin karşılaştırılması. Kuram ve Uygulamada Eğitim Bilimleri, 11(4), 2011-2043.

Downing, K. J. (2009). Self-efficacy and metacognitive development. The International Journal of Learning, 16(4), 185-199.

Ekici, G. (2005). Eğitim fakültesi öğrencilerinin öğretmenlik öz-yeterlik inançlarını etkileyen faktörler. XIV. Ulusal Eğitim Bilimleri Kongresi, 28-30 Eylül, Pamukkale Üniversitesi, Denizli.

Ekici, G. (2008). Sınıf yönetimi dersinin öğretmen adaylarının öğretmen öz-yeterlik alg1 düzeyine etkisi. Hacettepe Üniversitesi Ĕ̆itim Fakültesi Dergisi, 35(35), 98-110.

Fisher, M., King, J. \& Tague, G. (2001). Development of self-directed learning readiness scale for nursing education. Nurse Education Today, 21(7), 516-525.

Gibbons, M. (2002). The self-directed learning handbook. San Francisco: Jossey-Bass A Wiley Imprint.

Guglielmino, L. (1977). Development of the self-directed learning readiness scale (Unpublished Doctoral Dissertation). University of Microfilm International. Ann Arbor, Michigan.

Haron, S. (2003). The relationship between readiness and facilitation of self-directed learning and academic achievement: A comparative study of web-based distance learning models of two universities (Doctoral Dissertation). Universiti Putra, Malaysia

Hsu, Y. C., \& Shiue, Y. M. (2005). The effect of self-directed learning readiness on achievement comparing face-to-face and two-way distance learning instruction. International Journal of Instructional Media, 32(2), 143-155.

Karasar, N. (2012). Bilimsel araştırma yöntemi: kavramlar, ilkeler, teknikler. Nobel Yayın Dağıtım.

Karataş, K., \& Başbay, M. (2014). Öz yönetimli öğrenmeye hazırbulunuşluk düzeyinin eleştirel düşünme eğilimi, genel öz yeterlik ve akademik başarı açısından yordanması. Ilköğretim Online, 13(3), 916-933 .

Khan, S. A., Hussain, I., ud Din, M. N., Ahmed, M., \& Ahmed, S. (2012). Self directed learning in mathematics at secondary level. Academic Research International, 2(2), 168-171.

Knowles, M. S. (1975). Self-directed learning: A guide for learners and teachers. Cambridge: Englewood Cliffs.

Kuo, Y. C., Walker, A. E., Schroder, K. E. E., \& Belland, B. R. (2014). Interaction, Internet self-efficacy, and self-regulated learning as predictors of student satisfaction in online education courses. Internet and Higher Education, 20, 3550.

McLoughlin, C., \& Marshall, L. (2000, February). Scaffolding: A model for learner support in an online teaching environment. In Flexible futures in tertiary teaching. Proceedings of the 9th Annual Teaching Learning Forum (Vol. 2, No. 4).

Moore, M. G., \& Kearsley, G. (2012). Distance education: A systems view of online learning. Belmont, CA: Wadsworth-Cengage Learning. 
Oddi, L. F. (1984). Development of an instrument to measure self-directed continuing learning (Unpublished Doctoral Dissertation). Northern Illinois University, Illinois.

Özçelik, H. \& Kurt, A. A. (2007). İlköğretim öğretmenlerinin bilgisayar özyeterlilikleri: Balıkesir örneği. Elementary Education Online, 6(3), 441-451.

Pintrich, P. R. (2000). The role of goal orientation in self-regulated learning. In M. Boekaerts, P. R. Pinrich, \& M. Zeidner (Eds.) Handbook of self-regulation (pp. 451-502). San Diego: Academic Press.

Reio, T. G. (2004). Prior knowledge, self-directed learning readiness, and curiosity: Antecedents to classroom learning performance. International Journal of SelfDirected Learning, 1(1), 18-25.

Sarmasoğlu, Ş. (2009). Hemşirelik öğrencilerinin kendi kendine öğrenmeye hazıroluş düzeyleri (Yayımlanmamış Yüksek Lisans Tezi). Hacettepe Üniversitesi, Sağlık Bilimleri Enstitüsü, Ankara.

Schunk D.H. (1995) Self-efficacy and education and instruction. In Maddux J.E. (Eds), Self-efficacy, adaptation, and adjustment (pp. 281-303). The Plenum Series in Social/Clinical Psychology. Springer, Boston, MA.

Shinkareva, O. N., \& Benson, A. D. (2007). The relationship between adult students' instructional technology competency and self-directed learning ability in an online course. Human Resource Development International, 10(4), 417-435.

Stockdale, S. L. \& Brockett, R. G. (2010). Development of the PROSDLS:A measure of self-direction in learning based on the personal responsibility orientation model. Adult Education Quarterly, 20(10), 1-20.

Ulusoy, B., \& Karakuş, F. (2018). Lise öğrencilerinin öz yönetimli öğrenmeye hazırbulunuşlukları ile eleştirel düşünme eğilimlerinin incelenmesi. Mersin Üniversitesi Eğitim Fakültesi Dergisi, 14(2), 684-699.

Whipp, J. L., \& Chiarelli, S. (2004). Self-regulation in a Web-based course: A case study. Educational Technology Research \& Development, 52(4), 5-22.

Yaman, S., Koray, Ö.C. \& Altunçekiç, A. (2004). Fen bilgisi öğretmen adaylarının özyeterlik inanç düzeylerinin incelenmesi üzerine bir araştırma. Türk Ĕ̆gitim Bilimleri Dergisi, 2(3),355-364.

Yenilmez, K., \& Şan, İ. (2008). Matematik öğretmen adaylarının kendi kendine öğrenmeye hazıroluş düzeyleri. XVII. Ulusal Eğitim Bilimleri Kongresi, 1-3 Eylül, Sakarya Üniversitesi, Sakarya.

Zimmerman, B. J. (1989). A social cognitive view of self-regulated academic learning. Journal of Educational Psychology, 81(3), 329-339. 